University of Rhode Island

DigitalCommons@URI

Open Access Master's Theses

2020

\title{
CHANGING MOODS, BREAKING \& BUILDING BONDS: EXPLORING EVT THROUGH LITERARY REPRESENTATION
}

Tina Shanahan

University of Rhode Island, tinamshanahan1228@gmail.com

Follow this and additional works at: https://digitalcommons.uri.edu/theses

\section{Recommended Citation}

Shanahan, Tina, "CHANGING MOODS, BREAKING \& BUILDING BONDS: EXPLORING EVT THROUGH LITERARY REPRESENTATION" (2020). Open Access Master's Theses. Paper 1898.

https://digitalcommons.uri.edu/theses/1898

This Thesis is brought to you for free and open access by DigitalCommons@URI. It has been accepted for inclusion in Open Access Master's Theses by an authorized administrator of DigitalCommons@URI. For more information, please contact digitalcommons-group@uri.edu. 
CHANGING MOODS, BREAKING \& BUILDING BONDS: EXPLORING EVT

THROUGH LITERARY REPRESENTATION

BY

TINA SHANAHAN

A THESIS SUBMITTED IN PARTIAL FULFILLMENT OF THE

REQUIREMENTS FOR THE DEGREE OF

MASTER OF ARTS

IN

COMMUNICATION STUDIES

UNIVERSITY OF RHODE ISLAND 


\begin{abstract}
"Changing Moods, Breaking \& Building Bonds: Exploring EVT through Literary Representation" examines demonstrations of Expectancy Violations Theory (EVT) through embodied interactions of fictional characters. With a focus on Jane Austen's portrayal of interpersonal conflict, this exploration evaluates the theory of expectancy violations (EVT) through the study of the central pairings in Sense and Sensibility (1811) and Pride and Prejudice (1813), two of Austen's most celebrated novels, and observes how this theory illuminates interpersonal relationships in Austen's work. Moreover, it seeks to illustrate how the application of expectancy violations theory (EVT) to literary texts reveals concepts such as self-deception. There has been limited research connecting theories of communication to the literary novel. This study seeks to reveal how practicable concepts can explicate classical fiction and, therefore, increase its value.
\end{abstract}

The methodological approach to this research consists of a thorough examination of essays and critiques on Austen's work and a close reading of two of her acclaimed novels through an ideological lens, in which patterns, themes, and examples of expectancy violations theory (EVT) are interpreted. Additionally, this analysis examines a variety of studies done on expectancy violations theory (EVT), in order to establish how this theory illuminates the preoccupations behind Austen's novels. Finally, this research explores critical essays on the concept of self-deception, in order to demonstrate an influential relationship between expectancy violations theory and this recurrent, literary theme. 
At the heart of this analysis are two dissimilar relationships that, while having different results, inevitably still have to follow the same path in order to get there. Each of these partnerships encounter expectancy violations along the way, both positive and negative, and are inevitably confronted with self-deception. For Marianne, the heroine of Sense and Sensibility, this self-deception stems from a naïve world view, whereas the self-deception we see in Pride and Prejudice, arises from Elizabeth Bennet's humiliation caused by Mr. Darcy's unusual behavior. One of the more interesting dynamics of how these distinct relationships either flourish or disintegrate is that each is partially influenced by an outside source, raising the question as to whether other breaches of expectations would have been quite so impactful, had these external influences not been present - a question that can be answered with further research. The purpose of this study is to apply the familiar interpersonal theory of expectancy violations (EVT) to literature, offering an alternative perspective and understanding of the literary novel, and to illustrate why Austen's work is still significant today. 


\section{Acknowledgements}

I would like to express my sincerest appreciation to Dr. Kathleen Torrens. I would like to thank her for her guidance, support, and patience throughout this entire process. Had it not been for her willingness and interest in this project, this thesis would not have been possible. I would also like to thank Dr. Rachel DiCioccio for her critical insights and for talking me through the writing process at a time when I was "writing in circles." I am deeply grateful for both her assistance and for giving me clarity of mind. I would also like to thank Dr. Cheryl Foster. Both her knowledge and time were invaluable to me. I thank her for all of her guidance and for pointing me in the right direction so early on in this process. I could not have found my way without her. I would also like to thank Donna Torrey for being so wonderful at her job, and for always going above and beyond in order to get me to where I needed to be. I would also like to thank Sandra Baker for always lending me her ear, and for being such a joy to be around. Lastly, I would like to thank my family for being so patient and for

giving me the necessary time, space, and quiet weekends I needed in order to complete this project. For that, I am sincerely grateful. 


\section{Table of Contents}

Abstract..................................................................................ii

Acknowledgements.................................................................iv

Table of Contents..................................................................

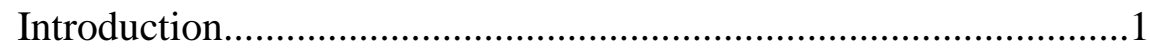

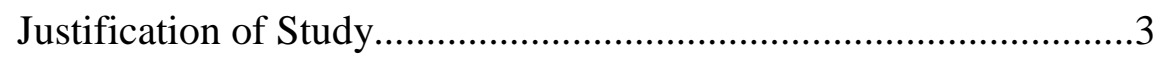

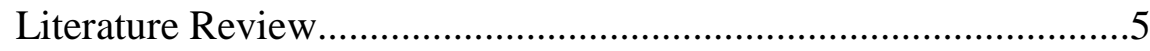

EVT: Applications in the Scholarly Literature..................6

Enduring Impact: Jane Austen and the Interpersonal...........9

Implications of Extant Literature for the Study............15

Content Analysis..............................................................21

Sense and Sensibility................................................22

Expectations and Rewards: Marianne's Fantasy Land.......26

Violations: Doses of Reality and Lavender Water..........32

Pride and Prejudice.......................................................44

Expectations: The Wickham Factor..................................48

Rewards: Elizabeth Bennet as a Tolerable Woman............50

Violations and New Expectations:

Reversing Judgments In Light of New Facts.................54

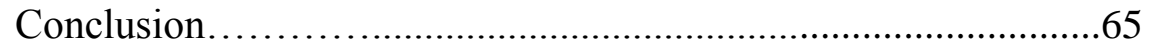

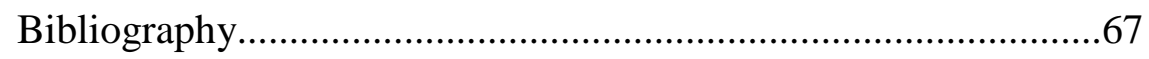




\section{Introduction}

More than 200 years since her death, and yet her work is still relevant today. Many people ask why - it has been critiqued and explored until there is nothing left to say, and yet we return to her work again and again for answers, for enlightenment, for entertainment. Jane Austen's novels continue to win the world over, even in modern society, a reality that she could never possibly understand. Or could she?

Many scholars argue that the reason Jane Austen's novels are so timeless is because she possesses an unusual understanding of human nature. Her work can be applied to any era because it doesn't cater to the fads of any specific time, but rather to the human mind. Jane Austen's gift is her incredible understanding of the motivations and desires of human beings, and it shows through the characters and societies she creates. Austen's work is a reflection of the world as she sees it, though not always written from a perspective that she necessarily agrees with. Most of Jane Austen's work looks at relationships, leading some to believe that her stories are nothing more than different variations of the marriage plot (Hinnant, 2006). However, her work offers far more than a mere marriage plot. It is a realistic narrative of how people come together or fall apart, based on their unique mindsets and conflicting desires, and how deviations from accepted norms can determine the entire course of a relationship. Many of Austen's most prominent relationships either thrive or fail based on deviations from accepted societal norms.

With a focus on Jane Austen's portrayal of interpersonal conflict, this exploration evaluates the theory of expectancy violations (EVT), a theory originally

focused on proxemics and social distancing violations which has, over time, evolved 
into a model used to evaluate reactions to unanticipated breaches in social behaviors, taking into consideration social expectation, the overall value placed on the violator, and the violation itself. Featuring Marianne Dashwood's relationship to John Willoughby in Sense and Sensibility (1811) and Elizabeth Bennet's relationship with Mr. Darcy in Pride and Prejudice (1813), this study observes how the theory of expectancy violations (EVT) illuminates interpersonal relationships in Austen's work. Furthermore, it seeks to illustrate how the application of expectancy violations theory (EVT) to literary texts reveals concepts such as self-deception. With limited research connecting theories of communication to the literary novel, this study seeks to reveal how practicable concepts can explicate classical fiction and, therefore, increase its value. 


\section{Justification of Study}

I chose to analyze Expectancy Violations Theory (EVT) and how it can be used to enrich literature for many reasons. Firstly, differences exist between relationships that thrive and those that fail; EVT offers one lens through which to explain those distinctions. Due to the theory's versatility, it can be applied to a variety of scenarios and situations, and because of that flexible nature, I believe that it will continue to evolve and remain relevant within the communication studies discipline. The decision to combine research in EVT with the works of Jane Austen comes from her enduring appeal, which makes a study of this kind more valuable. An examination of Sense and Sensibility and Pride and Prejudice, and more specifically, Marianne Dashwood and Elizabeth Bennet, comes from an interest in studying contrasting literary representations; one signifying oppression, and the other, female empowerment, a relevant topic in contemporary society.

A second reason for choosing to examine EVT in both Sense and Sensibility and Pride and Prejudice is that there is a direct relationship between the theory of expectancy violations and Austen's work. EVT is demonstrated time and time again throughout both novels as many of the central relationships follow the contours of this criteria, guiding the characters' actions and explaining their decisions to the reader. Although not previously addressed in any other studies, the shifts in each core relationship, from good to bad or bad to good, are the result of exceeded or violated expectations, which all through involve deliberate and corroborated elements of selfdeception. 
Self-deception, an important literary concept, is the third justification for undertaking this examination. A popular theme in many of Austen's works, selfdeception is what sends the heroines into the arms of villains, justifies the unfair judgments against the heroes, and is the number one cause of injury to many innocent bystanders. While not a result of expectancy violation, traces of self-deception within interpersonal relationships are frequently demonstrated by examining this theory, and so it remains among the central themes recognized at work in Austen's novels.

The main goal of this study is to demonstrate how theories of communication can increase the value of literature. By analyzing distinct and contrasting literary representations of interpersonal relationships, not only does it reveal the versatility of EVT, but also testifies to the enduring appeal of Jane Austen's work. Exploring her novels in this unique fashion both authenticates the theory and displays Austen's understanding of human nature, as her central relationships continuously follow the patterns of EVT. Additionally, the literary concept of self-deception is frequently demonstrated by examining the theory of EVT, thus reinforcing the value of exploring literature through this particular lens. 


\section{Literature Review}

Since its expansion in the mid-1980's from proxemics to other nonverbal cues, research on EVT has looked at a wide range of scenarios, without really focusing on any one in particular. Some have considered how students react to classroom breaches (Gigliotti, 1987), while others have studied violations brought about by music (Janata \& Petsche, 1993). One examination even considers the ramifications of an infringement by someone's favorite political candidate (Johnston et. al., 2012). Still, there has been no general consensus as to what ought to be made a priority.

The studies done on the novels of Jane Austen, however, have been a bit more focused. One of the most relevant explorations done on Austen, relevant because it provides the closest tie to be found between Austen's work and EVT, discusses the use of space in each of her novels (Hart, 1975), making several references to Hall, the father of "proxemics," which is the origin of EVT. Additionally, an overwhelming amount of research has examined and critiqued Austen's use of the marriage plot, since, at one time, that is all critics believed her works were about (Hinnant, 2006). To the contrary, many later studies admire Austen's ability to understand the human psyche, and create timeless pieces that could apply to the past, present, or future. Among the more popular research conducted on Austen's use of metaphors is that of Adams, in which he explores Austen's employment of dance as a symbol for courtship and marriage, closely examining the "unexpected" and "ill-timed" proposals that “reveal a character's nature" (Adams, 1982, p. 59). 


\section{EVT: Applications in the Scholarly Literature}

Although EVT can be found as an operational force beneath interpersonal relationships within the works of Jane Austen, scholars have thus far neglected to explore Austen's work as a context for understanding or applying EVT. Instead, they have opted to study the theory in relation to other topics, ranging from job satisfaction (Roberts \& David, 2019), to receiving unwanted, explicit materials through dating applications (Niehuis et al., 2019), to the moral fiber of movie characters (Bonus et al., 2019).

One study, for example, looks at students' abilities to give fair assessments of the courses that they take. The variables considered are students' first-day expectations, and whether or not those first-day expectations have been violated. Findings reveal that students do tend to give fair assessments, but that "reports at the end of the course account for almost all of the explained variance in the course rating items" (Gigliotti, 1987, p. 401). A related investigation explores "the expectations that students bring to a class" (Gigliotti, 1987, p. 365). The idea that expectations are a means of shaping perception was considered during this examination. This particular study observes the expectations that students brought to an introductory sociology course and analyzed both expectations and violations thereof. The results indicate that students' early expectations "are above average," (p. 365) and that the introductory course "generally results in a positive violation," (p. 365) although depending on sex, grade point average, and grade level, expectations may vary.

Other research looks at expectancy violations using spectral analysis. The purpose of this study is to demonstrate how "the dynamic process of musical 
expectancy can be studied by using several electroencephalographic (EEG) parameters such as amplitude or coherence in various frequency bands" (Janata \& Petsche, 1993, p. 281). Participants are asked to listen to cadences at different resolutions and give yes or no answers as to "how well the resolution matched their expectancy of the best possible resolution" (p. 281). Results confirm that "a form of expectancy operates in musical contexts, the results point towards the brain structures responsible for the processing of complex musical stimuli" (p. 281). In a related study, "a model of melodic expectation" (Margulis, 2005, p. 663), which assigned ratings "to the expectedness of melodic events" (p. 663) is proposed. The position of "expectations within the broader cognitive processes invoked in listening to music" (p. 663) is also observed, and "connections between the theorized expectations and the dynamic, affective contours of musical experience" (p. 663) is also outlined.

In one experiment researchers study brain, peripheral, and electrophysiological activity, as participants read both "positive and negative expectancy-consistent, expectancy-violating, expectancy-irrelevant, and semantically incongruent behavioral sentences about fictitious characters" (Bartholow et. al., 2001, p. 197). Results show that negative "expectancy-violating behaviors elicit enhanced negative affect" and that there are "enhanced positivities" in response to "expectancy violations and negative behaviors" (p. 197). There is also an indication that "semantically incongruent sentence endings influenced a separate negative component" which suggests that there are "fundamental differences between semantic- and behavior-consistency processing" (p. 197). 
Another analysis looks at the corporate world, and how the effects of positive and negative Corporate Social Responsibility (CSR) performance is evaluated for trustworthiness. Researchers discover that although "CSR performance does not significantly affect trustworthiness," (Lin-Hi et. al., 2015, p. 1944) "negative CSR performance significantly destroys trustworthiness" (p. 1944). Based on these findings, it is suggested that nonprofits should focus on responsible behaviors in order to have positive CSR performances and avoid distrust.

A survey conducted in the political arena reveals how emotion can impact political judgment. Looking at the "American National Election Studies" (Johnston et. al., 2012, p. 474), researchers examine "how the emotions of anxiety, anger, and enthusiasm" (p. 474) can influence an individual's opinion on candidates' political policies. Using expectancy violations as a framework, they find that "expectancyviolating emotions" (p. 474) have a tendency to "heighten deliberative reasoning and suppress partisan cue-taking, and that expectancy confirming emotions" (p. 474) have a "reverse set of effects" (p. 474).

One assessment that has gained a lot of attention focuses on an ambitious meaning maintenance model (MMM) that encompasses several different theories and suggests that "expectancy violations cause an arousing negative affective state" (Jones \& Jones, 2012, p. 350), but is reduced by natural human motivations because humans are uncomfortable in this negative state of being. The researchers explain their model, which "offers an integrated account of these behaviors, as well as the overlapping perspectives that address specific aspects of this inconsistency compensation process" (Proulx \& Inzlicht, 2012, p. 317). A related search explores the meaning-maintenance 
model, which "posits that any violation of expectations leads to an affective experience that motivates compensatory affirmation" (Randles et. al., 2013, p. 966). As part of this study, researchers examine whether or not acetaminophen can inhibit the "neural mechanism that responds to meaning threats" (p. 966). Using two separate experiments, participants are given either “acetaminophen or a placebo" (p. 966), and can be given "an unsettling experience or a control experience" on film (p. 966). Results reveal that when participants took the placebo they "showed typical compensatory affirmations by becoming more punitive toward lawbreakers, whereas those who had taken acetaminophen" (p. 966) did not.

Another exploration investigates the lack of research on "social-psychological interconnections between relationship development and interaction" (Barry \& Crant, 2000, p. 648), and develops a model of relational development within "organizational dyads" (p. 648). The study also examines how certain "communication properties and behaviors give rise to relationship attributions" (p. 648), and includes "expectancy confirmation and violation" in order to explain "how specific communication encounters lead individuals to reformulate attributions regarding the status of a given relationship" (p. 648).

\section{Enduring Impact: Jane Austen and the Interpersonal}

There have been a number of investigations into Austen's use of space throughout her novels, something with more direct implications for the application of EVT to the relationships in this study. Posusta, for instance analyzes various representations of space, suggesting that they can either signify "an intangible desire

or an oppressive reality" (Posusta, 2014, p. 77), compares the behavioral expectations 
of public and private settings, and explores how evolving psychological space creates "social change through both narrative description and a new accessibility of psychological landscape" (Posusta, 2014, p. 79). In a related examination of Austen's use of space, different degrees of distance are considered. This study is of particular interest, as a significant piece of the investigation assesses Hall's concept of "proxemics," the basis for Burgoon's model of EVT. This exploration addresses restrictions on societies in Austen's novels, and explains how small spaces and distances between characters affect privacy and relational development, both of which can lead to violations of expectations.

At one point in time it was a prevailing belief that Jane Austen's novels had only one plot (Hinnant, 2006), the marriage plot. However, more recent studies of Austen have ignored this claim. Many scholars believe that the reason Jane Austen is so timeless is because she had an acute understanding of the human psyche. George Butte and other scholars alike have been impressed by Austen's ability to demonstrate how characters could "perceive the reactions of another character to the first character's mental state" (Zunshine, 2007, p. 276), and have posed the question as to whether or not Austen led the way in literary intersubjectivity (Zunshine, 2007).

Others believe that it's the modernity of Austen's work that remains relevant, asking "why it is that Austen's fiction" in particular "can and does make a claim on its readers" (Kaufmann, 1992, p. 385). Shoben believes that Austen's work has a way of straddling different time periods - that her work can be applied to the past, present, and future. He agrees with literary critic, Trilling, who believes that "Austen's novels provide perspective on, a correction to, and a protection against the fads, the 
momentary forces, and the temptations of our own time" (Shoben, 1983, p. 521), and that these "fads, forces, and temptations arise in major degree from a universal and fundamental human experience that is at once affective and cognitive, emotional and intellectual, in its character" (Shoben, 1983, p. 521).

Some say that Austen's work has this capability because her novels are a reflection of her reality. Austen writes stories the way she sees the world before her. For instance, in her novel, Emma, the title character's “confusion about friendship mirrors the confusion expressed by eighteenth-century theorists and authors," (Thomason, 2015, p. 227) for "friendship, ideally in an egalitarian relationship, cannot thrive in a hierarchical society" (Thomason, 2015, p. 228). At that period in time, the concept of friendship was "both utilitarian and frivolous, both morally improving and morally risky," (p. 228) leaving philosophers in a struggle to give it a clear definition "and reconcile it with competing loyalties" (p. 228). This was a reality that Austen understood, and so her work reflects those observations.

According to Morini, Austen's novels are a mirroring of "a definite world view — a world view which has been interpreted in diametrically opposing ways" (Morini, 2007, p. 409). Where one reader might see her work as a narrative of her "invisibility," another might see it as "an upholder of the patriarchal values of her society" (p. 409), which have been challenged by "revolutionary" and feminist interpretations, where another, still, may look at her writing "as a satire on (excessive) sensibility" (p. 409). One scholar in particular feels that Austen's novels can be understood through her letters to her sister. If we take an alternative approach and read Austen's letters in terms of form, context, and style, "we can better understand her mind and character" 
and see them through the eyes of "their designated audience," the eyes of those "who were in on the joke" (Juhasz, 1987, p. 84).

Several critics of her work still prefer to observe Austen's focus on marriage, in both the literal and metaphorical sense. One assessment focuses on "women in marriage" (Lescinski, 1987, p. 60) as a reflection of "the growing ambiguity about and tension in the roles allotted to women by nineteenth-century society," discussing the heroines that Austen creates who defy these roles. A related study looks at the plot of courtship, discussing how each lover "must undergo" an anxiety inducing, "traumatic experience, a violent shift from innocence to self-knowledge before their union can be consummated" (Hinnant, 2006, p. 294). The exploration looks to illustrate how Austen uses different canonical plots in each of her novels, suggesting "that they reveal a far greater uneasiness about the premises of the courtship plot than might appear from a consideration of individual works in relative isolation from one another" (Hinnant, 2006, p. 295). A similar analysis on courtship and marriage investigates dancing as a metaphor and examines how characters interpret attentions and compliments, "in order to evaluate potential spouses," (Segal \& Handler, 1989, p. 322) also discussing how Austen advocates for her characters to avoid making judgments based on physical appearances. A comparable criticism looks at how "dances, balls, and singers" are a reflection on man's psychic life. From testing “a character's sense” (Elsbree, 1960, p. 115), to making a remark about "his attitude towards a particular partner" (Elsbree, 1960, p. 115), to revealing “a character's vitality” (Elsbree, 1960, p. 115), this study examines how "the plot's tempo" indicates the general rhythm of a character's life, a worthwhile endeavor considering that, excepting Persuasion (1818), all of Austen's 
novels use "the events of the dance to complicate the actions of the plot" (Elsbree, 1960, p .115).

Another relevant analysis concentrates on proposals, stating that "throughout the novels there are cases of marriage proposals that come unexpectedly, from the wrong person or at the wrong time or in the wrong manner, just as there are countless ill-timed dance proposals which reveal a character's nature" (Adams, 1982, p. 59). The proposal by Willoughby, for instance, is never clear to either party, indicating that perhaps Willoughby is concealing information about his true intentions, or his personal character. Another tactic that Austen uses are "moments of tension" (p. 59). An invitation that is expected never comes, casting doubt for both the heroine and the reader, inevitably causing an avoidable, but all too human misunderstanding, an occurrence "repeated with variations throughout the novel" (p. 59), which is an indication of Austen's understanding of interpersonal conflict.

An assessment which evaluates secrets looks at the "five secrets that keep Darcy and Elizabeth apart during the first half of the novel" (Stovel, 1989, p. 86), and considers how every secret is held by one of the pair but unknown to the other, creating a certain element of surprise, whereas an exploration of Austen's literary use of surprise discusses resulting emotional reactions, aesthetic form, self-correction, and the idea of moral surprises (Miller, 2005), the surprises which bring about knowledge and personal growth.

Several studies have also been done on self-deception, a theme frequently revealed by EVT, and a focus of my own research. One investigation looks at deception in a context of "rank, possessions, and manners" (Monaghan, 1975, p. 74), 
referring to Austen's "keen awareness" of how "the external image projected by the individual can be mere display or a means of deception" (p. 74), though this "is usually an accurate reflection of the inner man" (p. 74).

A survey on characters who self-deceive looks at Emma, a heroine who is liked by no one but Austen herself. It seeks to explore Emma's "willful" and "manipulative" destruction "of other people's lives" (Goodheart, 2008, p. 589), and considers whether or not she has gained any self-knowledge by the end of the novel. Austen was attracted to this type of character, according to Kauvar, whose research is centered on understanding "what influence, if any" did the Female Quixote have on Austen's writing? (Kauvar, 1970, p. 211).

Philosophical research on self-deception explores the "creation of characters" (Palmer, 1979, p. 47), suggesting "that a consideration of literature, of imagination" (p. 47), and "of the creation of characters, should result in a re-shaping of questions, answers and arguments of Logicians" (p. 47), while another philosophical approach, merely aims to define what self-deception means. According to Hamlyn, motivators for self-deception include the "fear of death and pain" (Hamlyn, 1985, p. 210). The study also differentiates between self-deception and lying, stating that "self-deception is not a pretense, for pretense implies the conscious awareness of what one is doing" (p. 210), and equates self-deception to repression. He further goes on to suggest that individuals can be "guilty" of self-deception because "if we are driven to selfdeception we are driven to what is in some sense a failure" (p. 210), however, a life void of self-deception is "an impossible ideal" (p. 210). 
At one point, the author suggests that there are "occasions when a person's self-deception will lead to harm to others" (p. 210), which brings Elizabeth Bennet's situation to mind - for she was so determined to dislike Mr. Darcy that she allowed herself to be influenced by Wickham, and as a consequence, her sister had an increased opportunity to elope with him. The author also mentions self-deception that only brings harm to the deceiver, asking whether or not it should be "tolerated in such cases" (p. 210), which brings to mind the circumstances surrounding Marianne Dashwood, whose self-deception was nearly fatal. Hamlyn's final thought revolves around the issue of philosophers themselves - for they consistently question whether or not the deception of self can even exist, therefore making it difficult to define, while an examination by Szabados, aims to address this philosophical limitation (Szabados, 1974).

\section{Implications of Extant Literature for the Study}

Since prior research hasn't made a connection between EVT and Jane Austen, it might not be easy to recognize, and so it's important to first explain what EVT is, and then briefly explore how it's displayed in Austen's novels. Whether one realizes it or not, the works of Jane Austen are full of expectancy violations. In a way, that's what Austen's stories are about - strict, societal expectations that, for one reason or another, the featured players fail to adhere to. Rather than immediately recognizing their own errors in judgment, Austen's characters must often embark on a journey toward personal growth in order to reap rewards, much like real life scenarios. To see how these unlikely pieces fit together, however, the reader must first understand the 
theory of expectancy violations. What is it, and how does it factor into Austen's stories?

Originally used "to explain proxemic behavior and communication" (Burgoon, 1993, p. 31), Expectancy Violations Theory (EVT) has since been expanded and renamed to include both verbal and nonverbal behaviors, as well as "emotional, marital, and intercultural communication" (Griffin, 2011, p. 88). As a complete and functional model, EVT is a communication theory that examines how individuals react to unexpected deviations from societal norms. An expectancy violation is an action that is "sufficiently discrepant from the expectancy to be noticeable and classified as outside the expectancy range" (Burgoon, 1995, p. 200). When we interact with someone who exhibits "unexpected behavior, our arousal increases. Arousal leads to an 'orienting response' in which we shift attention away from the topic of conversation to the interaction partner in an attempt to interpret and evaluate the unexpected behavior" (Wilson \& Sabee, 2003, p. 11).

EVT is generally considered to operate along three valences in sequential order: Expectancy, Communicator Reward, and Violation. The “expectancy” concept suggests an "enduring pattern of anticipated behavior" (Burgoon, 1993, p. 31), and can be either general (society's idea of what is typical and appropriate behavior) or particularized, which pertains to the typical interaction style of the individual, "which may differ from social norms" (Burgoon, 1993, p. 31). According to the theory of EVT, “expectancies for any interaction are derived from information about communicator characteristics, relational characteristics, and context” (Wilson \& Sabee, 2003, p. 11). Communicator characteristics include personality, communication 
style, and physical appearance. Relationship factors include familiarity, similarity, attraction, liking, and status equality between parties. Contextual components include "aspects of the environment" (White, 2008, p. 191) that could potentially influence how individuals would communicate in particular situations, such as "formality of the setting," (White, 2008, p. 191) the level of privacy available, or "task orientation" (Burgoon, 1993, p. 32).

Communicator reward valence, another concept of EVT, is the mental evaluation one uses once an expectation has been violated. Communicator reward valence is "the sum of positive and negative attributes brought to the encounter plus the potential to reward or punish in the future" (Griffin, 2011, p. 91). Communicator, relationship, and context - the factors that impact expectancies - are the same factors that "affect reward valence" (Burgoon, 1993, p. 34), with some components having more of an influence than others. These relevant components of communicator reward valence include "physical attractiveness, task expertise and knowledge, socioeconomic status, giving positive or negative feedback, possession of appealing - personal attributes, similarity to the perceiver, familiarity, and status equality with the perceiver" (Burgoon, 1993, p. 35).

Violation valence, the third concept of EVT is the "perceived positive or negative value assigned to a breach of expectations, regardless of who the violator is" (Griffin, 2011, 90). In the event that expectations are exceeded, a positive valence would be the result, which would theoretically produce "more positive interaction patterns and outcomes" (Burgoon, 1993, p. 40), whereas if less than expected is done, 
the result would be a negative valence, which could have detrimental effects on the relationship (p. 40).

To better understand how EVT ties in with her works, we can look at Austen's novels, where it is frequently demonstrated along the arc of specific interpersonal relationships. In Sense and Sensibility we see it with Marianne Dashwood and Willoughby, and in Pride and Prejudice, we see it time and time again between Elizabeth Bennet and Mr. Darcy, but EVT can also be demonstrated through the interactions with other characters as well, and while this thesis does not focus primarily on these supporting characters, it is worth examining how EVT functions within their interactions with others, as illustrative of how such interactions proceed in alignment with the process of EVT.

John Dashwood, for instance, violates expectations in Sense and Sensibility when he promises his father that he will financially assist his sisters and stepmother. However, after his father passes away, his wife, Fanny, convinces him that "to take three thousand pounds from the fortune of their dear little boy, would be impoverishing him to the most dreadful degree" (Austen, 2011, p. 12). As a result, Dashwood agrees to give them "fifty pounds a year a-piece" (Austen, 2011, p. 20), send them away from Norland, and keep their china, since it will be "a great deal too handsome" "for any place they can ever afford to live in" (p. 20). As time goes by, however, he never ends up assisting them at all. At a dinner party later on in the novel, expectations are further violated when Elinor Dashwood's painting abilities are devalued by his wife Fanny and her mother. This event has a negative impact on the 
reward valence, which is seen later when Marianne, Elinor, and Mrs. Jennings "all joined in a very spirited critique upon the party" (Austen, 2011, p. 498).

The presence of EVT is also evident throughout Pride and Prejudice. Mr. Collins, a prime example, violates expectations even before he arrives at Longbourn. The letter received by Mr. Bennet, for example, paints the picture of a very ridiculous man. From it, Mr. Bennet gathers that Mr. Collins is "a mixture of servility and selfimportance" "which promises well" (Austen, 2012, p. 122). In other words, Mr. Bennet realizes that Mr. Collins is a fool who will "provide amusement" (Shapard, 2012, p. 123) because he clearly does not understand social norms. This is proven when Mr. Collins spends his first evening with the Bennet family, passing the time praising his patroness, Lady Catherine de Bourgh. He brags about her "affability and condescension" (Austen, 2012, p. 128) and informs them that she even "once paid him a visit in his humble parsonage" (p. 128), which we immediately learn is separated from her residence "only by a lane" (Austen, 2012, p. 130).

The more Mr. Collins has to say, the more ridiculous he sounds, further violating expectations, and negatively affecting the reward valence, meaning that no one with any sense would consider it beneficial to further interact with him. This is made clear when Elizabeth rejects his proposal of marriage, and the subsequent mortification when her good friend, Charlotte Lucas, does not. "The strangeness in Mr. Collins's making two offers of marriage within three days was nothing in comparison of his being now accepted" (Austen, 2012, p. 244), for Charlotte, as the wife of Mr. Collins, "was a most humiliating picture" (p. 244). Mr. Collins proposing 
and Charlotte accepting has created a negative valence for Elizabeth, as there is no one in the world less deserving of her good friend, than him.

Through my thesis research, I will be exploring the three valences of EVT expectancy, communicator reward, and violation - in both Sense and Sensibility and Pride and Prejudice. In Sense and Sensibility, I will discuss how Willoughby's attractiveness surpasses Marianne's expectations, which influences her opinion of his character, and causes her to overlook his flaws to the point where she deceives herself into believing that he is a victim and Colonel Brandon, who genuinely cares for her, is a villain. In Pride and Prejudice, I will examine how Mr. Darcy's initial slight toward Elizabeth negatively violates her expectations and reveals her self-deceptive belief that Wickham is a gentleman and Darcy is a scoundrel. I will also discuss how a series of later revelations positively violates Elizabeth's expectations, and shifts the entire dynamic of her and Darcy's relationship. The reason this study matters is because it reveals that Austen's novels are not just a mere marriage plot, but instead an accurate reflection on how relationships work. Further, it demonstrates the validity of EVT and how it can be applied to a variety of scenarios. Finally, it demonstrates a relationship between violated expectations and the act of self-deception. 


\section{Content Analysis}

Sense and Sensibility and Pride and Prejudice are two distinct novels with one comparable experience. The parallels are noticeable; two women, each of whom is a sister, two men vying for their love, two villains, but two very different outcomes. Marianne, who represents sensibility, feels too much, yet cannot express what she does not feel. Elizabeth, prejudiced and headstrong, never hesitates to express how she feels. In Sense and Sensibility, the outcome for Marianne nearly costs her her life. In Pride and Prejudice, Elizabeth inherits Pemberley, complete with a husband who's worth ten thousand a year. With both stories, the hero needs the villain in order to prevail. Darcy needs Wickham in order to prove that he is not the cad Elizabeth thinks he is, and Colonel Brandon needs Willoughby so that Marianne will eventually come to appreciate Brandon as the more worthy man. Both women have their expectations violated and fall into the trap of self-deceit; Marianne, later, Elizabeth, early on. The difference between the two is not that Elizabeth ends up with the man she loves, and that Marianne has to shift her priorities in order to find happiness. The difference is in their mindset. Elizabeth represents the strong, independent woman, who would not permit a Willoughby to infect her heart to the degree that Marianne does. Marianne, on the other hand, represents the oppressed girl who, though it may not seem like it on the surface, doesn't recognize her own self-worth. For if she did, she might realize that Willoughby's attraction toward her is merely superficial. He likes her because she is attractive and because of her interests. Colonel Brandon, on the other hand, truly appreciates Marianne for her person, for her talents, and for what she, herself, brings to the world. 
The methodological approach used for this research consists of a thorough examination of essays and critiques on Austen's work and a close reading of two of her acclaimed novels through an ideological lens, in which patterns, themes, and examples of expectancy violations theory are interpreted. Additionally, this analysis examines studies done on expectancy violations theory (EVT), in order to establish how this theory illuminates the thematic emphases behind Austen's novels. Finally, this research explores critical essays on the concept of self-deception, in order to demonstrate a cause and effect relationship between expectancy violations theory and this recurrent, literary theme.

\section{Sense and Sensibility}

\section{Sense and Sensibility: A Summary}

Sensibility is said to have "interested Jane Austen from her earliest work to her last" (Tave, 1973, p. 74), which might explain why Marianne, who represents sensibility, is so central to the novel. Sensibility, at the time, referred to "a person's general emotional consciousness or feelings, as well as, most significantly, a particular acuteness and sensitivity of feeling" (Austen, 2011, p. xxiv), which could include “compassion for suffering and the unfortunate, empathy with others' feelings, love of natural beauty, delicate artistic taste, and instinctive aversion toward immorality" (Austen, 2011, p. xxiv). The decision to satirize Marianne came from Austen's desire to expose "all those senses and sensibilities that dominate social life and that are poor substitutes for the real thing" (Valihora, 2010, p. 195). 
In the opening of Sense and Sensibility, the family patriarch, Mr. Dashwood, has died leaving his son, John, with the responsibility of financially supporting his half-sisters, Marianne, Elinor, and Margaret, and his stepmother, Mrs. Dashwood. However, after his father's passing, and at his wife's insistence, John refuses to assist them, and they are ultimately forced to leave their home.

Upon their arrival at Barton cottage, their new home in Devonshire, they are greeted by Sir John Middleton to whom they owe much gratitude, for it is he who has brought them here. At this time they are introduced to his neighbor, Mrs. Jennings, and his good friend, Colonel Brandon. It is obvious early on that Colonel Brandon likes Marianne, which leaves her feeling very unsettled because he doesn't meet her expectations. Nearly twenty years her senior, Colonel Brandon does "not seem to be a good match for the young, energetic, and emotional Marianne" (Nixon, 1998, p. 22). She feels that he is too old and too infirm to be a suitor. She also doesn't believe in second attachments, even though her mother was her father's second wife.

One afternoon, when Marianne and her sister, Margaret, are taking a walk, Marianne ends up getting hurt. As she is telling her sister to get help, a man approaches, lifts her up, and brings her back home. Once there, Marianne gets a good look at her rescuer, and discovers that John Willoughby is by far the most attractive man that she has ever seen. He promises to return, and return he does. Upon getting to know him better, Marianne finds that his tastes and opinions are all her own - it's as if he were an extension of Marianne, herself! In all actuality, however, these similar tastes are Willoughby's way of expressing his attraction for her. 
As time goes on, Marianne becomes increasingly attached to Willoughby, who "fulfills her dream of an ideal lover" (Lauber, 1993, p. 32) and increasingly oblivious to Colonel Brandon (except when she and Willoughby are making fun of him). It soon becomes apparent to everyone, including Colonel Brandon, that an engagement is imminent. One day, however, Willoughby is abruptly called away. He claims that he must go on an errand to London, and he doesn't know when he'll be back, and Marianne's sister, Miss Dashwood, notices that his behavior is circumspect and unusual.

While Willoughby is away, Marianne and her sister, Elinor, are invited to go stay in town for the winter. While at an assembly, after many months of not seeing or hearing from Willoughby, Marianne spots him in a circle of others, but when he approaches her and Elinor, he acts strangely, and can barely look at Marianne. When she asks him why he won't speak to her, he ignores her questions, and quickly excuses himself from their company. This makes Marianne very agitated, prompting Elinor to look for Mrs. Jennings so that they can leave.

The next morning, Marianne receives a letter from Willoughby, in which he tells her that he never intended for her to form an attachment. To reinforce his position, he returns all of the letters that Marianne has previously sent him. Her sister, who thought that they were already engaged cannot understand this sudden change, but when she presses Marianne for information, she is told that she and Willoughby were never engaged, and that Willoughby has done nothing wrong.

Dissatisfied with Marianne's explanation, Elinor speaks with Colonel Brandon and learns that Eliza Williams, Colonel Brandon's ward and daughter of his first love, 
has been ruined by Willoughby, left with a child, and because he refuses to marry her, Willoughby has been cut off financially from his wealthy relation, and must now marry one Ms. Grey, who happens to be very wealthy. Elinor relays this information to Marianne, with the hope that it will make Marianne see Willoughby for what he truly is. Unfortunately, this news does not have the intended effect, as Marianne deceives herself into believing that Willoughby is a victim who is being forced by circumstances into a prudent marriage. Marianne's denial about the reality of the situation makes her excessively ill, almost to the point of dying.

When Colonel Brandon learns of Marianne's illness, he rushes off to Barton to bring her mother back to town, and in the process of doing so, confesses his love for her daughter. Once Marianne begins to recover, the family returns to Barton. As time goes by and her illness has stripped her of the sexual vitality that has blinded her to Brandon and Willoughby's true natures, Marianne reevaluates her feelings for Colonel Brandon, coming to the realization that "one can love twice," and "that Brandon isn't senile." (Garis, 1968, p. 66). As her feelings for Willoughby decrease, her feelings for Colonel Brandon increase - as she gradually learns to integrate ethical admiration and aesthetic appreciation - and she eventually agrees to marry him.

On one level, Sense and Sensibility is “another version of a young lady’s entrance into the world" (Pinion, 1983, p. 86), but on another level, it is a study in human communication. Throughout the novel, there are several illustrations of EVT, starting from the time when Marianne discovers that Colonel Brandon has taken an interest in her. "Marianne is young, intolerant, an absolutist of sensibility" (Lauber, 1993, p. 31), and has specific ideas about what a suitor should and should not be. 
When Colonel Brandon, who is considerably older than she is, makes it clear that he likes Marianne by the attention he pays to her musical abilities (and she reminds him of someone from his past), that violates her expectations. On the other hand, when she meets the "handsome, charming Willoughby," (Pinion, 1983, p. 86) whose tastes are so similar to her own "that at times" he seems like "Marianne's creation" (Lauber, 1993, p. 32), her expectations are exceeded. However, when she eventually learns that he "has been guilty of unprincipled conduct" and "has abandoned the girl he seduced," forcing him to give up Marianne, "with whom he is in love, to make a mercenary marriage" (Pinion, 1983, p. 86), he, too, violates her expectations, and when Marianne “finally acknowledges Willoughby's treachery - it nearly kills her” (Lauber, 1993, p. 31).

In the sections that follow, I will further elaborate on how EVT is illustrated throughout the story, and how this theory illuminates the literary novel.

\section{Expectations and Rewards: Marianne's Fantasy Land}

Marianne Dashwood is a romantic idealist with a very particular set of unrealistic standards. She is in "ardent pursuit of all the most romantic ideas and notions of her time" (Kaye-Smith \& Stern, 1944, p. 25), has a fondness for nature and the picturesque, reads Cowper and Scott, and is exceedingly intolerant of those who are not expressive or sentimental. A very young seventeen, Marianne has already known "desperation which had seized her" (Austen, 2011, p. 94) only months before, fearing that she may never meet "a man who could justify her ideas of perfection" (p. 94). 
Unlike Austen, the character of Marianne Dashwood holds opinions, "based upon novels of the sixties and seventies in which intuitive reaction is seen as more laudable than obedience to convention because it is more 'natural' - that is, more rational" (Waldron, 1999, p. 67), an attitude that was not all that uncommon, but not a reflection of who Austen was, herself. There are a few known similarities between Austen and Marianne, however, including their shared "admiration of Cowper, Thomson and Scott" (Kaye-Smith \& Stern, 1944, p. 26), and although a majority of Austen's heroines are modeled after her own image, with "a clear and reasonable quality” (Kaye-Smith \& Stern, 1944, p. 9), and Marianne's “youthful enthusiasm, warmth and sensibility" (Kaye-Smith \& Stern, 1944, p. 25) portrayed through the character of Marianne that positions her as "one of Jane's most endearing portraits" (p. 25) appears to miss the mark, Marianne is still able to demonstrate that quality of reason through her musical talents.

Beyond her music, however, reason has a tendency to fall short, for at seventeen, she has already given up and resigned herself to the idea of spinsterhood and the only reason she even changes her mind is because John Willoughby walks into her life, delivering the fantasy that she thought would never come to life. To her juvenile imagination, Willoughby, who "appears in the guise of knight and rescuer and carries Marianne in from the rain" (Valihora, 2010, p. 208), "is to the stricken damsel nothing less than a romantic hero" (p. 208).

Thus, in light of this study's emphasis on the three valences of EVT, Willoughby exceeds Marianne's expectations from the very moment that they meet. By displaying a valuable quality, his ability to be depended on in a difficult situation, 
Willoughby has influenced Marianne's opinion of him. His "heroic" act of carrying her in from the rain has placed him in a favorable light, and the likelihood of her wanting to interact with him in the future has now increased, leaving the worries of never in her life meeting the "perfect man" now, according to Marianne's young mind, "rash and unjustifiable" (Austen, 2011, p. 94).

In addition to this marker of dependability, Willoughby also has the quality of attractiveness in his favor. Of his exterior qualities, it is said that, "his person and air were equal to what her fancy had ever drawn for the hero of a favourite story" (Austen, 2011, p. 82). This feeling extends to her mother and sisters, as Austen also says that, "his manly beauty and more than common gracefulness were instantly the theme of general admiration, and the laugh which his gallantry raised against Marianne received particular spirit from his exterior attractions" (Austen, 2011, p. 80). EVT proposes that "individuals who are physically attractive, powerful or highly competent are typically seen as more rewarding than those who do not have any (or all) of those characteristics" (White, 2008, p. 192). In addition to being dependable, Willoughby is handsome and his "abilities were strong" (Austen, 2011, p. 94), further strengthening his reward value. Increasingly agreeable in her eyes, it soon becomes apparent that whenever Willoughby is in her presence, Marianne can see nobody else. "Every thing he did was right. Every thing he said, was clever" (Austen, 2011, p. 100). As Marianne's impression of him is so enthusiastic from the beginning, it is no surprise that she is eager to approve of him, although his "cleverness" can likely be attributed to his tendency to agree with everything that Marianne says. Early on, it is revealed that her qualifications for any potential male suitor are outlandish and 
unrealistic when she says, "I could not be happy with a man whose taste did not in every point coincide with my own. He must enter into all my feelings; the same books, the same music must charm us both" (Austen, 2011, p. 30). After spending a limited amount of time with Willoughby, Marianne learns that he is "passionately fond" of music and dancing, causing her to give him "such a look of approbation as secured the largest share of his discourse to herself for the rest of his stay" (Austen, 2011, p. 88).

One risk of Marianne's quick judgment about Willoughby and her expectations, however, is ambiguity as to whether he genuinely agrees with her; it is possible that he is just performing a part. "Getting to know and appreciate another person usually involves time and effort" (Bernstein, 2001, p. 28), but Marianne and Willoughby seemingly mirror each other in nearly every aspect since the time of his arrival. "Their taste was strikingly alike. The same books, the same passages were idolized by each" (Austen, 2011, p. 90). "Instant understanding," says Bernstein, "is usually the result of someone recognizing how you would really like to be seen and pretending to see you that way" (Bernstein, 2001, p. 28). Willoughby may or may not have tastes that are exactly like Marianne's, but based on his past behavior (to be revealed in the following section), it is reasonable to believe that he is, in fact, grooming her for his own selfish purposes. According to Bernstein, grooming is "a slow, seductive dance that leads you to behave like your own evil twin by crossing one little line at a time" (Bernstein, 2001, p. 45), which is initially seen between Willoughby and Marianne while they're having a conversation about Colonel Brandon. 
Marianne doesn't like him, and Willoughby knows this and so he uses this information to his advantage. "Brandon is the kind of man,' said Willoughby one day, when they were talking of him together, 'whom every body speaks well of, and nobody cares about; whom all are delighted to see, and nobody remembers to talk to"” (Austen, 2011, p. 96). Since Willoughby sees Colonel Brandon as his foe and is aware of Marianne's comparable dislike of the man, he capitalizes on these moments with her, cruelly bonding over a common enemy. He anticipates that she will agree with him, and just as predicted, she does, stating, "That is exactly what I think of him" (p. 96). The effect this creates is that there is now one more opinion of hers which he (sincerely) endorses, and an additional increase in his reward value, an effect that can also be produced when an extravagant gift is given to a girl who is a "mix of idealism and self-occupation" (Waldron, 1999, p. 76-77).

Not long after their acquaintance begins, "Willoughby had given her a horse, one that he had bred himself on his estate in Somersetshire, and which was exactly calculated to carry a woman" (Austen, 2011, p. 110). Willoughby reveals the news to Marianne first. If she is able to keep the horse, not only does it increase her regard for him, but it also serves as a constant reminder of his generous character. If she is forced to reject the offer, Willoughby can demonstrate both regret and a caring attitude, increasing his value yet again, and allowing him to appear even more endearing, while Marianne places the blame elsewhere. Knowing that she has nowhere to keep his extravagant gift, Marianne probably realizes that there will be an objection by either her mother, or more likely, her sister, especially as Willoughby has made the gift when he is only "so lately known to her" (p. 110). It is thus fitting that, in relaying the news 
to her sister about the horse, Marianne uses the name "Willoughby" for the first time “without 'Mr.' before it" (Shapard, 2011, p. 111), an indication that had his only intention been to appear more favorable to Marianne, his plan clearly would have worked. Then again, he may have been attempting to increase trust, so that when he brought her to Allenham, she wouldn't object, but would instead spend "a considerable time there in walking about the garden and going all over the house" (Austen, 2011, p. 128), an activity that would be frowned upon because "unmarried men and women should not have extensive intimate contact" (Shapard, 2011, p. 131), and "going all over the house together would be worse, both for the extensive contact away from others' eyes and for their probably going into bedrooms together" (p. 131).

However, "dim as our understanding of Marianne is, we are positive that she would never get into this sort of trouble" (Garis, 1968, p. 66), as "Austen fortunately wasn't interested in or capable of Richardsonian pornography about such a figure" (p. 66). Although, if given his own separate consciousness, a decision like this leads right back to the possibility that Willoughby is grooming Marianne, encouraging her to violate her own rules by speaking to "the teenager inside" (Bernstein, 2001, p. 43), describing "all the wonderful possibilities that life holds" (p. 43), if only she is "just willing to take the risk" (p. 43). Considering her high regard for him, and the fact that she really is just a teenager, is it that unreasonable to assume that John Willoughby was planning on doing to her what he had previously done to Eliza Williams?

As Garis reminds us, Austen isn't interested in taking the work in that direction, and so we instead arrive at the expectation of a marriage proposal. With all of their interests aligned, the mutual dislike of a man whom "nobody remembers to 
talk to" (Austen, 2011, p. 96), an extravagant gift, and a visit to Allenham, a proposal would naturally be the next step. Although there is no public announcement, everyone expects it, though Elinor is skeptical, even after she learns from their youngest sister, Margaret, that Marianne and Willoughby "were whispering and talking together" (Austen, 2011, p. 114); he asked her for something and then "took up her scissors and cut off a long lock of her hair" (Austen, 2011, p. 114), which "was frequently used as a memento of love" (Shapard, 2011, p. 115). When Elinor hints at the possibility of a future marriage, Marianne neither confirms nor denies an engagement, as she isn't engaged, and "does not want this to surface while she clings desperately to romantic ideals of true love unhampered by mundane formal covenants" (Waldron, 1999, p. 77). However, given that Willoughby hasn't disappointed so far, there is no reason not to hold on to that "tight knot of brooding passion" (Hawkridge, 2000, p. 127), and the firm belief "that he will offer her marriage" (p. 127).

\section{Violations: Doses of Reality and Lavender Water}

As significant as John Willoughby's arrival is in Marianne Dashwood's life, his departure from Barton is equally impactful. When Willoughby suddenly leaves for London, this begins a new pattern between him and Marianne - one in direct contrast with what Marianne is both used to and has come to anticipate. Rather than exceed all of her expectations, he now begins to violate them, a change which ultimately transforms Marianne's perception of reality.

"One becomes aware in shifts of location from social to personal distance (and vice versa)" (Hart, 1975, p. 314). When transitioning from "social to personal distance" (p. 314), this shift can feel like an invasion, or "an imposition of intimacy" 
(p. 314), neither wanted nor expected. However, "to move abruptly in the opposite direction" (p. 314) can be equally devastating, for it can signal "a breaking off of intimacy in exclusion or retreat" (p. 314). Willoughby’s abrupt announcement to Marianne that he is leaving Barton on an "errand" and doesn't know when he'll return, a lie one tells to "protect the self-image of the person telling the lie" (Bryant, 2008, p. 26), is a violation of expectations for Marianne, a conclusion that can be deduced based on her reaction. According to EVT, our arousal becomes heightened when a violation occurs, forcing the individual who has been violated to make sense of the violation, and evaluate "the positive or negative value of the violation" (White, 2008, p. 191). Marianne's initial reaction to the news, in which she comes "hastily out of the parlour apparently in violent affliction, with her handkerchief at her eyes; and without noticing them ran up stairs" (Austen, 2011, p. 144), not only tells us that a violation has occurred, but also indicates that Marianne places a considerable amount of importance on proximity. Although the theory initially proposed that "violations create physiological arousal" (White, 2008, p. 191), "later work has suggested that the process need not involve this type of activation" (p. 191), and that "arousal" can be described "in terms of an alertness or orientation response" (Burgoon, 1993, p. 35). Therefore, a more realistic scenario suggests that Marianne's extreme display of emotion is highly unlikely. Additionally, research has shown that "an abrupt departure" (p. 35) by "a person who is highly regarded" (p. 35) "may be perplexing to the perceiver but is likely to be excused as based on some urgent need" (p. 35), and would only be "interpreted as an intentional slight" (p. 35), if the "perceiver suffers from low self-esteem" (p. 35). However, many scholars also believe that Marianne 
was created as a satirical character (Valihora, 2012), so that is something to keep in mind, especially when evaluating her reactions to "unforeseen circumstances." That, and she is a teenager.

After Willoughby departs from Barton, Marianne and her sister, Elinor, are invited into town for the winter. Reluctantly, the Dashwood sisters decide to go. Every day while they are out shopping, Marianne spends her time on the lookout for Willoughby, with the belief that he is staying somewhere nearby. It has been quite a while, and Marianne has heard nothing from him. She has written letters, but they repeatedly go unanswered, and when she asks the footman if any servant or "porter has left any letter or note" (Austen, 2011, p. 304), "the man replied that none had" (p. 304), leaving her with a very unsettled feeling, and left to interpret the meaning behind his silence. Even after leaving his card for Mrs. Jennings, indicating that he has arrived in town, Willoughby continuously neglects to visit Marianne, or respond to any of her notes. This leaves her twice as disappointed when messages are delivered to the house, and prompts her to suspect that something is amiss. According to Burgoon, in a situation such as this one, "the act itself is normally not evaluated positively" (Burgoon, 1993, p. 38), but "the fact that it was committed by someone held in high regard might cause it to be evaluated neutrally" (p. 38). In spite of Willoughby's ongoing silence, Marianne continuously waits for him to call on her, as she accompanies Mrs. Jennings and Elinor to various social gatherings. After one meeting in particular, she learns that Willoughby has been invited, but declines to attend. Following this event, after he still fails to contact her, Marianne grows melancholy, and begins to sink into a depression "wholly dispirited, careless of her appearance, and 
seeming equally indifferent whether she went or staid" (Austen, 2011, p. 322), as she prepares to go to an assembly "without one look of hope or one expression of pleasure" (p. 322). "Violation Valence" refers to the "positive or negative value we place on a specific behavior, regardless of who does it" (Griffin, 2011, p. 90). Based on Marianne's reaction to Willoughby's failure to attend the party, we can now assume two things; first, Marianne views his absence as a slight, and a violation, and second, Marianne assigns more weight to the act of "being present," than she does to written correspondence. Although she is upset when he doesn't write her back, she becomes far more agitated when he either leaves, or has the ability to be with her, but chooses to be elsewhere. Realizing that Willoughby is making a conscious choice to ignore her, Marianne is now becoming aware of the "shift" from personal to social distance (Hart, 1975).

Shortly after arriving at the latest gathering, which she is indifferent about attending, Marianne experiences a temporary moment of relief when she finally spots Willoughby in the crowd. However, when he anxiously approaches, momentarily leaving his mysterious female companion behind, he neither looks at nor speaks to Marianne, instead directing all conversation toward Elinor. Of his behavior, Austen says that, "he could not then avoid it, but her touch seemed painful to him, and he held her hand only for a moment. During all this time he was evidently struggling for composure" (Austen, 2011, p. 324), and when Marianne confronts him about his behavior he evades her questions as "his complexion changed and all his embarrassment returned" (p. 324). He finally answers her, but only briefly, and then quickly departs from their company, not because he is "trying to make matters worse" 
(Gottman \& Gottman, 2016, p. 135), but because he is "trying to calm down" (p. 135). According to Gottman, this is a natural reaction when men become "physiologically aroused" (p. 135). "They leave. They stonewall" (p. 135), they try to "prevent face loss” (Metts \& Grohskopf, 2003, p. 361). Coincidentally, this same type of "physiological arousal" causes Marianne to storm "hastily out of the parlour apparently in violent affliction" (Austen, 2011, p. 144), during their last encounter. Nonetheless, his hasty departure, also known as the flight response (Shapard, 2011, p. 135), distresses Marianne a great deal and is evaluated as another significant violation, an indication that any future interactions would produce little or no reward, and an affirmation that the transition from personal to social distance is complete (Hart, 1975).

Thus far, we have two distinct violations of Marianne's expectations. Firstly, Willoughby has failed entirely to remain in touch with her, respond to her letters, or acknowledge her presence in town. Second, he exacerbates and adds to these violations by slighting her in person and in public, even upon direct confrontation by Marianne. The following day, Willoughby follows up with a third violation, "a revoltingly heartless letter" (Smith, 1972, p. 92) in which he "apologizes” for any confusion, revealing that he has been engaged for some time, and soon to be married to someone else. He then writes, "it is with great regret that I obey your commands of returning the letters, with which I have been honoured from you, and the lock of hair, which you so obligingly bestowed on me" (Austen, 2011, pp. 336-338).

The news shocks Marianne, who "is incapable of subduing or disguising her emotions" (Smith, 1972, p. 92), leaving her to feel miserable and dejected, and 
creating another negative violation, not least one based on a lie, as Marianne has not in fact commanded that he return her letters at all. When Colonel Brandon arrives at the house a few days later, he discloses to Elinor that Willoughby is a very dishonorable young man, having lured Colonel Brandon's ward into a sexual liaison, impregnated her, and then "left the girl whose youth and innocence he had seduced, in a situation of the utmost distress, with no creditable home, no help, no friends, ignorant of his address! He had left her promising to return; he neither returned, nor wrote, nor relieved her" (Austen, 2011, p. 388). He made "a promise, which the liar does not intend to keep" (Scott, 2016, p. 10), doing so in order to "avoid loss" (Agosta et. al., 2013, p. 256).

Once his wealthy relation, Mrs. Smith learns of his indiscretions, she disowns Willoughby, causing him to lose his inheritance, forcing him to abandon Marianne (though he has not indicated this to her) and seek out a rich woman to marry. He has no real affection for the woman, but marries her all the same. According to Gottman, "the affiliations of females are important in organizing many societies" (Gottman \& Gottman, 2016, p. 152). "Females, not males, determine the social hierarchy of the group. Evolutionary biology tells us that females should have more developed attachment and affiliation systems than males" (p. 152). "Marianne's mistake," says Gillie, "is not that she wants her marriage to be a love match or nothing, but that she insists on behaving as though the social circumstances are unreal"' (Gillie, 1985, p. 128), just one more way that Marianne deceives herself. She "wants to marry without deference to society's prejudices, but her romantic lover plays her false because he loves money too much" (p. 128). He's also an unworthy man who would corrupt 
Marianne's young mind, as "Colonel Brandon's ward reminds us of the really high dangers to which Marianne's reckless impropriety might have led" (Garis, 1968, p. 66). However, when Elinor relays all of Willoughby's bad deeds to Marianne, rather than dissolve her suffering, the newly discovered details only serve to increase the severity of the situation, nearly bringing Marianne to an early grave because she is struggling with self-deception, which is revealed through Willoughby's negative violations.

Self-deception can best be defined as "an arrogant self-presentation" "whereby we construct an image of ourselves more pleasing to ourselves" (Grenberg, 2015, p. 164). Differing from "a lack of self-knowledge” (Palmer, 2016, p. 356), selfdeception is an unconscious disguise (Minma, 2001) that can reveal itself in the attitudes toward other characters (Palmer, 2016). The self-deception seen in Austen's novels proves "to be a common failing, that hinders one from acknowledging the truth, and because of it individuals as well as society suffer" (Ashfaq, 2014, p. 92).

We see this failing from Marianne throughout the novel, as she repeatedly mistakes Colonel Brandon for the villain, and Willoughby for the hero. To her, Willoughby is "a man who could satisfy" her "ideas of perfection" (Austen, 2011, p. 94). He is her ideal, and that is why it is not surprising when he so easily influences her consistent rejection of Colonel Brandon, of whom she states "has neither genius, taste, nor spirit. That his understanding has no brilliancy, his feelings no ardour, and his voice no expression" (Austen, 2011, p. 98). This statement is not born from a place of truth, but instead comes from a superficial comparison to her feelings for Willoughby. 
This character deficiency that reveals itself in the practice of self-deception may not, however, fall solely on the shoulders of Austen's heroines. H.W. Garrod believes that the problem lies within the heroes and villains themselves because Austen's "bad young men are much nicer than her heroes... They are nice; Willoughby is nice, Wickham is nice" (Garrod, 1928, p. 39). Austen's villains also have a tendency to "hide their intentions, and thus their true natures, behind a moral façade," (Taschereau, 1977, p. 86) whereas, her heroes display their flaws freely, just strutting around like peacocks. There are times when "the reader has no way of knowing some males are bad" (Taschereau, 1977, p. 87) until Austen reveals it. "Sooner or later she relates of them the piece of wickedness which makes them wicked" (Garrod, 1928, p. 39).

In the meantime, as it is so eloquently stated in Pride and Prejudice, "One has got all the goodness, and the other all the appearance of it" (Austen, 2012, p. 436). Where Willoughby fits the "type" for the romantic hero, Colonel Brandon upsets this stereotype. Critics have argued that Brandon has "dull common sense" (Waldron, 1999, p. 78), and that "his age and demeanor in the present of the novel fit him for the position of mentor/guardian" (Waldron, 1999, p. 79). For many, he isn't considered to be a heroic character at all when, for a majority of the novel, "he is a shadowy figure, spending the bulk of his time mooning about and making half-declarations of vicarious love in unfinished sentences to the sister of the girl he wants" (Hawkridge, 2000, p. 147), and his only two notable actions are when he takes "a long and dramatic ride to fetch" (p. 147) Marianne's mother, and when he narrates, for Elinor, "the bad character and selfish cruelty of Willoughby" (Helm, 1909, p. 141). 
The eventual pairing of Marianne and Brandon has also been criticized, as it only appears to serve as "a facile, even perfunctory resolution, designed to fulfill the contemporary requirement for a heroine of excessive sensibility to be either punished or reformed" (Waldron, 1999, p. 82). "She is persuaded to marry a dull but reliable husband who will keep her on the straight and narrow path" (p. 82), only after being forced to accept Willoughby's vicious character. "The very worthy and very dull Colonel Brandon” (Helm, 1909, p. 141), a good man, but by no means much else. According to Garis, in Sense and Sensibility, "learning feels like losing something, giving up some hope or some possibility; after an unsuccessful gamble at freer living" (Garis, 1968, p. 61). When her hopes of a life with Willoughby fail, all Marianne can really do is "creep back defeated to the boundaries of sense" (p. 61) to marry "the safe and reliable Colonel Brandon" (Gillie, 1985, p. 128).

Where the first argument suggests that Colonel Brandon is to blame, the counter argument suggests that the reason for Marianne's self-deception comes from a flaw within Marianne herself. Colonel Brandon is a well-respected, honorable man who has never shown anything but kindness and appreciation toward Marianne and the rest of her family. However, Marianne refuses to see this, even after he has previously sat through her concerts, and given her the compliment of undivided attention, when no one else would because all Marianne cares about are the superficial qualities; the "aches, cramps, rheumatisms, and every species of ailment that can afflict the old and the feeble" (Austen, 2011, p. 72). She is "prejudiced against him for being neither lively nor young" (Austen, 2011, p. 96) and says that he is old enough to be her father "and if he were ever animated enough to be in love, must have long 
outlived every sensation of the kind" (Austen, 2011, p. 70). She pokes fun of his use of "flannel waistcoats" (Austen, 2011, p. 72), and considers his interest in her absurd, considering his "advanced years and "forlorn condition" (Austen, 2011, p. 68). Even a "prior attachment," which was the result of a "perverseness of circumstances" (Austen, 2011, p. 106) that were beyond his control, Marianne cannot, or rather, will not, be prevailed upon to look past. However, for all of Colonel Brandon's alleged shortcomings, and the expectations he violates based on his lack of liveliness, brilliancy, ardour, expression (Austen, 2011, p. 98), and those wretched "flannel waistcoats" (Austen, 2011, p. 72), the problem doesn't lie with Colonel Brandon, but with Marianne, herself.

Late in the novel Elinor censures Marianne on account of Willoughby's selfish behavior (Austen, 2011, p. 654), although her censure could just as easily be directed at her own sister because like Willoughby, Marianne is egocentric. Brandon, who contradicts her narrow world view and her "exemplary" relationship with Willoughby is perceived as a threat, and therefore, automatically violates her expectations, whereas Willoughby's supposed similarities to Marianne, not only assure her that he is the "ideal," but serve to validate her, as well. She responds positively to Willoughby because of his ability to mirror her, which "makes Willoughby into an extension of herself" (Shoben, 1983, p. 531) and "the hero of a favourite story" (Shoben, 1983, p. 530), a role he "quite willingly participates" in (Shoben, 1983, p. 530) by agreeing with every opinion, interest, and desire, exceeding her expectations every time he does. According to Bartholow, "expectancies encourage an individual to avoid others who seem threatening and approach those who appear trustworthy" (Bartholow et. al., 
2001, p. 197). For Marianne, Brandon's age, dullness, flannel waistcoats, and contentious relationship with Willoughby constitute a threat, whereas Willoughby's behavior signifies trustworthiness because it is so much like hers.

According to Shoben, "her love for him is a form of self-love, a feature of her narcissism" (Shoben, 1983, p. 531), driven by her "impulses toward self-actualization" (Shoben, 1983, p. 531), which, according to Maslow, is "experiencing fully, vividly, selflessly, with full concentration and total absorption. It means experiencing without the self-consciousness of the adolescent" (Maslow, 1965, p. 111). If Willoughby were less like Marianne, or perhaps, stopped pretending to be so much like her, she wouldn't find him nearly as "clever" and interesting, and she would be less likely to compare Brandon so harshly against him.

Such is not the case, however, and throughout the novel Willoughby "egocentrically capitalizes on her narcissistic infatuation, using it to increase her accessibility and his uncommitted enjoyment of her" (Shoben, 1983, p. 531), and over time, "Marianne violates with increasing seriousness the norms of her society" (Shoben, 1983, p. 531) as she indulges in the "histrionics of sensibility" (ApRoberts, 1975, p. 361), while Willoughby, with all of his "trifling, pleasing, opportunistic behavior" (Elsbree, 1960, p. 117), is eager to encourage this. However, when he inevitably disappoints, rather than keeping her head, "Marianne lets her joy, anxiety, or grief so overwhelm her that she behaves like a person crazed" (Ryle, 1968, p. 107).

An adapted version of EVT includes low and high arousal intensity dimensions for when a violation occurs (Burgoon et. al., 1989). In Marianne's case, nearly every violation in which Willoughby either leaves or avoids her, results in a high-positive, 
excited arousal, because similar to someone who is codependent (Beattie, 1992), Marianne is reactionary. She reacts "to the problems, pains, lives, and behaviors of others" (Beattie, 1992, p. 37), and she reacts to her "own problems, pains, and behaviors" (p. 37) and so as a result of "her physical resistance" (ApRoberts, 1975, p. 362) which has gradually "been lowered by sensibility as has her psychic resistance" (ApRoberts, 1975, p. 362), and her refusal "to say what she did not feel" (Austen, 2011, p. 230), she eventually has a mental breakdown. Although her breakdown stems from more of an emotional cause and less from a cold, this "hysterical" illness that Marianne experiences, is not all in her head (Bernstein, 2001). Histrionic afflictions are real and their sufferers "really are sick. How they get sick is the unanswerable question” (Bernstein, 2001, p. 115), although many histrionic illnesses are "psychological, ranging from agitated depression to delayed posttraumatic stress" (p. 115 ) with symptoms that "are usually pervasive, confusing, and frustratingly sporadic" (p. 115). Marianne's malady, as we know, develops from a cold acquired by a nighttime walk, but transforms into something far more severe and dangerous due to "the many weeks of previous indisposition which Marianne's disappointment had brought on" (Austen, 2011, p. 584).

Her disappointment, however, is born out of unrealistic expectations. For Marianne, Willoughby represents an Adonis; a Herculean figure without fault. Only, the real man with all his deficiencies intact cannot live up to her invented version of him. Logically, she knows this, however, she is desperate to hold on to that previous image and convince herself that Willoughby is guilt free (Burgoon, 1993) because the idea that he would be willfully cruel is too painful for her to handle (Hamlyn, 1985). 
More importantly, it wouldn't feed into her own vanity. Therefore, instead of accepting reality, Marianne falls into a fantasy, and for her own "cognitive comfort," places blame on others, rather than on Willoughby, which is where it belongs. However, once this charade is over, and she is forced to accept and let go of the illusion of a man that doesn't really exist, and re-evaluates her own priorities, coming to terms with her own selfishness, she is finally able to recognize that Colonel Brandon was the better man all along.

This section has evaluated the valences of EVT and the revelation of selfdeception from the perspective of Marianne Dashwood in Sense and Sensibility. The following section will also explore the valences of EVT and the revelation of selfdeception, but from the perspective of Elizabeth Bennet, a more empowered character, in Pride and Prejudice.

\section{Pride and Prejudice}

\section{Pride and Prejudice - A Summary}

Originally called 'First Impressions,' Austen completed her most famous novel “in August 1797 and eventually renamed it Pride and Prejudice," (Halperin, 1984, p. 57) finally having the work published in 1813. Centered on the Bennet family, this story focuses on Elizabeth, the second of five daughters, and the only one her father does not think of as "silly," and Fitzwilliam Darcy, a wealthy aristocrat.

The story of Elizabeth and Mr. Darcy begins at a ball, when Darcy refuses to stand up for a dance with Elizabeth, telling his friend, Mr. Bingley, that "she is tolerable; but not handsome enough to tempt me" (Austen, 2012, p. 20). This 
comment, overheard by Elizabeth, injures her pride and leaves her dismayed because it is unusual that someone should be so publicly rude. "Darcy's unsociable behaviour is not" at all "normal for a man in his position" (Waldron, 1999, p. 49) and it defies societal norms, especially when there is a "scarcity of gentlemen" (Austen, 2012, p. 18) at the assembly, and all dancing occurs in pairs (Austen, 2012, p. 19).

In the meantime, Mrs. Bennet, who is determined to see her daughters marry well, schemes to have her eldest, Jane, go to Netherfield and make Mr. Bingley fall in love with her. Shortly after arriving, however, Jane falls ill and must stay at Netherfield for an extended period of time, prompting Elizabeth to follow her sister and stay at her bedside. While there, Elizabeth is forced to endure Bingley's sisters and, of course, Mr. Darcy. While he doesn't make a positive impression on her, he finds that she has made a lasting one on him.

Shortly after arriving home, Elizabeth accompanies her younger sisters into the village of Meryton, where they meet their friends from the regiment, and a new man named Mr. Wickham. While there, Darcy and Bingley arrive. Mr. Wickham sees Darcy, and after some hesitation, touches his hat - "a salutation which Mr. Darcy just deigned to return" (Austen, 2012, p. 144) and only does so because doing nothing at all would be considered very ungentlemanlike by societal standards (Shapard, 2012, p. 145). Observing Elizabeth's reaction, Wickham takes the opportunity to paint a most unfavorable picture of Darcy, insisting that he is the reason for all of Wickham's current misfortunes. Darcy's alleged slight toward Wickham, following his slight toward her, reinforces her negative opinion of the man, and so she is all "too willing to 
accept Wickham's stories because they so nicely confirmed her own feelings about Darcy" (Moler, 1968, p. 102).

Keeping an earlier promise that he made to the Bennet sisters, Mr. Bingley throws a ball at Netherfield. Unfortunately for Elizabeth, the majority of her family, as well as her foolish cousin, Mr. Collins, suffers from an etiquette deficiency. The night results in Elizabeth's humiliation and the removal of Darcy, Bingley, and Bingley's sisters from Netherfield. Upon learning of their removal Elizabeth's sister, Jane, is heartbroken and Elizabeth is convinced that this is a ploy by Darcy to keep Jane and Bingley apart.

Soon after Darcy's and Bingley's exit, Mr. Collins also takes leave of the Bennet family, although his departure is on account of a marriage proposal, which Elizabeth promptly turns down. However, within three days of this rejection, Mr. Collins is accepted by Elizabeth's friend, Charlotte. After the wedding, Elizabeth is invited to Charlotte's new home in Kent, and subsequently meets Lady Catherine de Bourgh, Mr. Collins' patron who also happens to be Darcy's aunt. During Elizabeth's visit to the Collinses, Darcy and his cousin, Colonel Fitzwilliam, arrive and, ignorant of the connection, Colonel Fitzwilliam reveals to Elizabeth that Darcy intentionally and proudly separated Bingley from Elizabeth's sister, Jane. Unaware that Colonel Fitzwilliam has recently shared this information, Darcy proposes to Elizabeth, but finds that his feelings are unrequited, and that Elizabeth has some feelings of her own in regard to his insulting behavior toward her, her sister, and Mr. Wickham.

Following this rejection, Mr. Darcy writes Elizabeth a letter, exposing Wickham's character, revealing that Wickham once attempted to seduce his (Darcy's) 
young sister, suggesting that Darcy understands how "Wickham's personal charm of manner" could have "allowed him to make such a very good impression on Elizabeth" (Davidson, 2017, p. 17). He also discloses that prior to leaving Netherfield, he sincerely believed that Jane was indifferent to Bingley, which is why he tried to keep the two apart. Upon reading this, Elizabeth realizes that she may have been misled by Wickham, a notion that is reinforced when she later meets Darcy's sister, and sees for herself that Ms. Darcy is not the spoiled, cold, or selfish character Wickham made her out to be.

Elizabeth's opinion of Wickham changes yet again when she learns that her youngest sister, Lydia, has run off and eloped with him. Where she initially believes that Darcy, in light of this news, will never speak to her again, she soon discovers that he has tracked down Wickham and Lydia and has forced them to marry, so that the Bennet family name, and more importantly, Elizabeth, can be spared. When she learns of all that he has done to save her family, Elizabeth Bennet finally comes to appreciate Mr. Darcy for the man that he is, and subsequently consents to become his wife.

"Female readers always rate Mr. Darcy of Pride and Prejudice as a romantic favorite because he is so deliciously decent" (Priloeau, 2013, p. 63), a truth that someone probably should have shared with Elizabeth Bennet, much earlier on. From Elizabeth's perspective, Mr. Darcy is a man who violates her expectations by insulting her during their first encounter, prevents her "friend," Wickham, from having a decent living, and destroys her sister's chances of a happy marriage. With these negative impressions against him, the only action powerful enough to change the course of events is the selfish behavior illustrated by Mr. Wickham and Elizabeth's sister, Lydia, 
prompting Darcy to save the day, and effectively, the reputation of the Bennet family. Had someone informed Elizabeth of Darcy's character earlier on, she may have been spared from all of the aggravation. Then again, that wouldn't make for much of a story.

\section{Expectations: The Wickham Factor}

By the time Elizabeth Bennet meets Mr. Wickham, her opinion of Mr. Darcy is already quite low, for when she first encounters Darcy, he refuses to stand up and dance with her, stating to his friend, Mr. Bingley that, "she is tolerable, but not handsome enough to tempt me; I am in no humour at present to give consequence to young ladies who are slighted by other men. You had better return to your partner and enjoy her smiles, for you are wasting your time with me" (Austen, 2012, p. 20). Due to this initial humiliating event, it isn't all that difficult for Wickham to convince Elizabeth that Darcy is an infamously bad man.

Elizabeth is first introduced to George Wickham, the newest member of the regiment, while escorting her sisters, Kitty and Lydia, into town. Exceeding her expectations in looks and manners, his first positive "violation," the two begin a conversation. As they are speaking, Bingley and the "abominable" Darcy appear down the road on horseback. As Bingley and Darcy approach the Bennet sisters and their military friends, Darcy and Wickham take notice of each other. After some moments of hesitation, Wickham cautiously acknowledges the former, and Darcy gives him a flimsy allowance in return, before riding off. At her uncle's house later that evening, Wickham tries to evaluate Elizabeth's opinion of Darcy, which doesn't take long. Of Darcy she says, "I have spent four days in the same house with him, and I think him 
very disagreeable" (Austen, 2012, p. 152). Once Wickham learns of her general dislike of the man, he takes the opportunity to "enlighten" Elizabeth as to the particulars of his and Darcy's former acquaintance. He first informs her that he and Darcy are "not on friendly terms" (Austen, 2012, p. 154). Wickham continues on with his tale, revealing that he grew up with Darcy, as his own father was the late Mr. Darcy's steward. He tells Elizabeth that he was supposed to be a member of the clergy, but after the elder Mr. Darcy passed away, he was denied the opportunity by the son. Again, Wickham has positively “violated" Elizabeth's expectations by reinforcing her negative opinion of Mr. Darcy. According to Paris, the set up here is like a court of law. "Elizabeth and Wickham are the plaintiffs and Darcy is the defendant. Because Darcy injures her pride, Elizabeth is disposed to believe Wickham's false testimony against him" (Paris, 1978, p. 99), but the problem with this arrangement "is that Elizabeth is unconsciously using Wickham to reinforce her prejudice against Darcy and is, as a consequence, allowing herself to be used by Wickham to reinforce his own false position" (Poovey, 1998, p. 89).

In an attempt to further this false position, Wickham takes the opportunity to comment on Darcy's sister, Georgiana, saying that she too is very proud, just like her brother, after Elizabeth reveals that "everybody is disgusted with his pride" (Austen, 2012, p. 152), adding that Wickham would not find Darcy "more favourably spoken of by anyone" (p. 152). Over the course of the conversation, it becomes increasingly clear that Elizabeth is taken by Wickham, though it's not her heart that is engaged, but rather "her understanding" (Morgan, 1980, p. 83). "Her opinion of him is based on her 
belief in her own discernment and her separation through intelligence from an essentially ugly world" (p. 83).

By the end of their exchange, and after Wickham has swayed her to believe that Darcy's abhorrent behavior against him is due to "some measure of jealousy" (Austen, 2012, p. 158), Elizabeth now wholeheartedly believes that Darcy is a cruel man who "deserves to be publicly disgraced" (Austen, 2012, p. 156), which could be seen as a third positive "violation" because it gives Elizabeth "permission" to think poorly of Mr. Darcy. According to Burgoon, "expectancies serve as perceptual filters, significantly influencing how social information is processed" (Burgoon, 1993, p. 32). Since Elizabeth already has such negative feelings toward Darcy, all of Wickham's claims go unchallenged, fortifying her already ill opinion of the man. At the conclusion of their conversation she is thoroughly convinced that Mr. Darcy is the most proud and conceited individual that she has ever known. However, "in accepting Wickham at face value, Elizabeth repeats the folly of the naive protagonist in the eighteenth century novel" (Duckworth, 1971, p. 121), and exhibits signs of selfdeception.

\section{Rewards: Elizabeth Bennet as a Tolerable Woman}

It has already been established that Elizabeth Bennet considers Mr. Darcy to be quite the intolerable human being. Not only has he negatively violated her expectations by refusing to dance with her at their first meeting, but she has also been told that he has brought a great deal of misfortune to a very recent, yet very agreeable acquaintance, Mr. Wickham. Between these two offenses, and others that will be 
discussed shortly, Elizabeth Bennet has decided that Mr. Darcy is the most despicable man that she has ever met!

After Darcy publicly insults Elizabeth by refusing to dance with her, she considers it an unforgivable offense and a personal affront. According to Burgoon, expectations of strangers are based on social norms "and context factors like the type of interaction and setting" (Burgoon, 2015, p. 2). Consequently, when Elizabeth, her mother, and her good friend, Charlotte Lucas, are discussing the events of the evening later on, and Charlotte says that Darcy's pride doesn't bother her, Elizabeth responds, "I could easily forgive his pride, if he had not mortified mine" (Austen, 2012, p. 36), and tells her mother, "I may safely promise you never to dance with him" (p. 36). According to Tanner, Elizabeth's early reactions to Darcy are her "settled habit" (Tanner, 1986, p. 106). "She identifies her sensory perceptions as judgements, or treats impressions as insights" (Tanner, 1986, p. 106). Following their encounter, Elizabeth has no intention of seeing Darcy ever again, if she can help it.

Unfortunately for Elizabeth, there is no avoiding him, thanks to her crafty mother, who is determined to see Elizabeth's sister, Jane, marry Mr. Bingley - who happens to be staying at Netherfield with Mr. Darcy. In an ill-conceived plan to make Bingley fall in love with her daughter, Mrs. Bennet sends Jane to Netherfield on horseback, in the rain, the action of "a thoroughly stupid mother" (Kaye-Smith \& Stern, 1949, p. 103), "who speaks another language" (Brower, 1964, p. 64). Shortly after arriving, when it is clear that she is sick, the doctor is called in, and Jane and Bingley are prevented from spending much time together. Learning of her sister's present condition and knowing that her foolhardy mother won't go to see her, 
Elizabeth walks to Netherfield to be at Jane's side, an activity that "heightens her value and renders her suspect in Darcy's eyes" (Chandler, 1986, p. 36). During her stay, while not attending her sister, Elizabeth is unable to avoid Darcy, and the tension between them is felt, as Elizabeth subtly insults Darcy for what she perceives as arrogance. At one point, when Darcy speaks of ridiculing "wise men," Elizabeth takes the opportunity to notify him of her bitterness and disdain for both him and his pride, saying, "I hope I never ridicule what is wise and good. Follies and nonsense, whims and inconsistencies, do divert me, I own, and I laugh at them whenever I can. But these, I suppose, are precisely what you are without" (Austen, 2012, p. 108).

Although he tries to impress upon her that pride is not a weakness, informing her that "where there is a real superiority of mind, pride will be always under good regulation" (p. 108), Elizabeth remains unmoved, and when she and Jane leave a few days later, after receiving the sincere promise of a ball from Bingley, Elizabeth cares for Darcy no more now than when she first met him. According to Burgoon, early expectancies persist through an "interaction to its conclusion" (Burgoon, 1993, p. 32). Elizabeth has already made up her mind about Darcy, so even though his behavior is more pleasing than before, she still views him in a negative light.

Staying true to his word, Bingley, by and by, throws a ball at Netherfield. All are invited, including Elizabeth's family who are in the habit of making a spectacle of themselves everywhere they go. In addition to her parents and her siblings, Elizabeth's ridiculous cousin, Mr. Collins, is also in attendance. He has been staying with the Bennet's temporarily, as he looks for a future wife and spends his days talking about his patroness, Lady Catherine de Bourgh, who is, coincidentally, Darcy's aunt. Over 
the course of the night every member of the family, excepting Jane and Elizabeth, draw unfavorable attention toward themselves, including Mr. Collins, who forces his acquaintance on an unamused Darcy. As catastrophic as the evening is, the news that Darcy and the Bingleys have departed from Netherfield, shortly thereafter, is even more distressing, as Elizabeth is certain that this is Darcy's attempt to divide Bingley from Jane. Based on Elizabeth's history with Darcy, she expects him to use his haughty authority to divide her sister from his friend, and in this instance, she is correct, and although Darcy feels justified in taking the Bingleys and leaving Netherfield, based on the disastrous evening with the Bennets, for Elizabeth, this is yet another negative violation.

After the residents of Netherfield take their leave, Mr. Collins decides to leave, as well. After Elizabeth rejects his proposal of marriage, much to her father's relief, he (Mr. Collins) is almost immediately accepted by her friend, Charlotte. Although Elizabeth is disappointed, and her expectations of Charlotte's judgment are violated by her friend's decision to marry Mr. Collins (on account of his being such an idiot), she nonetheless agrees to come and visit Charlotte following the wedding. During her stay, Elizabeth meets Lady Catherine de Bourgh, and "in the course of a few weeks" (Austen, 2012, p. 332), Darcy and his cousin, Colonel Fitzwilliam, arrive as well. Colonel Fitzwilliam, unaware of Elizabeth's familial connections, discusses the extent of his cousin's “kindness” when he tells her of Darcy's generous and recent rescue of "a friend from the inconveniences of a most imprudent marriage" (Austen, 2012, p. 364) because "there were some very strong objections against the lady" (p. 364). This could be considered yet another negative violation by Darcy because even though 
Elizabeth had an idea that he would try to keep Bingley and Jane apart, she probably didn't consider the possibility that he would brag about it.

When she hears this upsetting news, Elizabeth is prompted to return to the Collins' home under the guise of a headache. As she sits there pondering this recent revelation, examining all of the cheerless "letters which Jane had written to her since her being in Kent" (Austen, 2012, p. 370), Darcy appears, first to check on her, and then to propose, saying, "In vain I have struggled. It will not do. My feelings will not be repressed. You must allow me to tell you how ardently I admire and love you" (Austen, 2012, p. 372). Unfortunately for Darcy, he finds that his feelings are not shared. In fact, Elizabeth has some very different feelings in regard to him, in spite of his professions of love (Burgoon, 1993, p. 33). She censures him for his manner of proposing (Austen, 2012, p. 374), for "ruining, perhaps for ever, the happiness of a most beloved sister" (p. 374), and for Wickham's "present state of poverty" (Austen, 2012, p. 376). While he doesn't deny separating her sister and his friend, he does defend his apprehensive feelings toward Elizabeth considering that her "condition in life is so decidedly beneath" (Austen, 2012, p. 378) his own. With such an unorthodox and insulting proposal, this is yet another negative violation of Elizabeth's expectations. However, after Elizabeth dismisses him, frustrated over her accusations on behalf of his adversary, Darcy decides to write to her and unveil a different image of Wickham than what she has previously known, forcing Elizabeth to re-evaluate her perspective.

Violations and New Expectations: Reversing Judgments in Light of New Facts 
Not much time passes after receiving Darcy's letter before Elizabeth returns home to Longbourn. She tells her sister, Jane, of the proposal, although she omits Darcy's role in her (Jane's) and Bingley's separation. In thinking about Darcy's letter, she begins to look at Wickham more objectively, particularly when considering the circumstances surrounding his engagement to a young heiress, who has recently inherited a large fortune. She struggles to accept the truth, though. "Even after reading, and rereading, Darcy's letter, Elizabeth still struggles with partiality and blindness" (Valihora, 2010, p. 270) because "even when we know better, we still cannot help it" (p. 270). However, when Elizabeth is made aware that the brief engagement between Wickham and the heiress has ended, and when Lydia says of Wickham that "he never cared three straws about" (Austen, 2012, p. 426) the young lady, Darcy's assertions of Wickham appear to be confirmed.

According to Bonito, "positive violations are socially valued behaviors that exceed the quality of anticipated actions" (Bonito et. al., 1999, p. 231). For Elizabeth, this is a positive violation because she would never have known what kind of man Wickham was, if Darcy hadn't so willingly shared personal information for her benefit. Now aware of Wickham's true character, Elizabeth becomes alarmed when her sister, Lydia, wants to travel with the regiment to Brighton. She pleads with her father not to allow her to go, but it is done in vain, as he has no desire to listen to both Lydia's and Mrs. Bennet's complaints if he says no, and as Darcy has requested that Elizabeth not divulge his private family information in regards to Wickham, she can give her father no concrete reason for her objections. 
After Lydia departs, Elizabeth goes away with her uncle and aunt, the Gardiners, on a holiday tour. Relatively close to Pemberley, they all agree to visit the property, as the family, the Darcys are away. Overwhelmed by the sight of the lavish property, Elizabeth quietly says to herself, "And of this place” (Austen, 2012, p. 476), "I might have been mistress" (p. 476). Here, again, is another positive violation of Elizabeth's expectations. Although she was aware that Darcy is wealthy, she never in a million years would have expected anything quite so grand. (Bonito et. al., 1999). They speak with the housekeeper, who admits them entry. She gives them a tour of the home, speaks highly of Darcy, and shows them portraits of the family. As she speaks, Mrs. Gardiner takes notice of a miniature photo of Wickham. When the housekeeper sees this, she tells them that he is the son of the late steward, who has "gone into the army” (Austen, 2012, p. 478), "but I am afraid he has turned out very wild” (p. 478). As Elizabeth and the Gardiners take a final turn around the property, Darcy arrives, unexpectedly, and in much better spirits than usual. He is friendly to Elizabeth, and is very hospitable toward her aunt and uncle. As Darcy offers her uncle use of his property to go fishing, Elizabeth wonders, "Why is he so altered? From what can it proceed? It cannot be for me - it cannot be for my sake that his manners are thus softened. My reproofs at Hunsford could not work such a change as this. It is impossible that he should still love me" (Austen, 2012, p. 494). Only, now that she has seen Pemberley, along with Darcy's altered behavior, she starts to hope that he still does (Bonito et. al., 1999). He invites them back again, and requests that Elizabeth meet his sister, Georgiana, an entreaty which she doesn't dare refuse. For Elizabeth, 
this is yet another positive violation because their relationship may be moving in a direction which they now both desire (Bonito et. al., 1999).

The following day Elizabeth meets Georgiana Darcy, and is pleasantly surprised to find that she is nothing like the character that Wickham previously described. Elizabeth "had heard that Miss Darcy was exceedingly proud; but the observation of a very few minutes convinced her that she was only exceedingly shy. She found it difficult to obtain even a word from her beyond a monosyllable" (Austen, 2012, p. 504). Georgiana's manners serve as a positive violation because her behavior confirms Mr. Darcy’s claims (Bonito et. al., 1999). With Darcy's claims against Wickham confirmed, Elizabeth slowly starts to recognize her own prejudice, though the full effect is not seen, until she receives a troubling letter from home.

One morning, while reading Jane's letters, which have previously been misdirected, Elizabeth discovers the terrible news. Jane informs Elizabeth that Colonel Forster has sent a late night express, informing the Bennet's that Lydia "was gone off to Scotland with one of his officers; to own the truth, with Wickham! Imagine our surprise" (Austen, 2012, p. 524). The news shocks Elizabeth, as she considers the ramifications of her sister's and Wickham's actions. Not only does this incident sour Lydia's name, but it has the potential to ruin the entire family, eliminating the possibility that any of the remaining sisters might marry well. "The great humiliation" (Tave, 1973, p. 128) for Elizabeth, though, "is the discovery that she has believed all he says of Darcy because she has been pleased by his preference and offended by Darcy's neglect, therefore courted prepossession and ignorance and driven reason away" (p. 128). 
As she ruminates over all of the possible implications of Lydia's disastrous decision, Darcy arrives. Although he believes Elizabeth to be ill, she feels that she cannot conceal the truth, and so she tells him what has happened. Upon hearing the news, Darcy quickly departs, and Elizabeth is convinced that he never wants to see her again. Here, he has negatively violated her expectations. Elizabeth is finally developing feelings for Darcy, but because of a situation that is out of her control, he may end up abandoning her, after all (Bonito et. al., 1999). When the Gardiners receive word of what has happened, the reaction is considerably different, as Mrs. Gardiner "cannot think so very ill of Wickham" (Austen, 2012, p. 542). Cutting their tour short, the Gardiners rush Elizabeth back to Longbourn and then return back home themselves. At first, there is little information; no one can locate Lydia or Wickham, and there has been no news of a marriage. Within a few days, however, the Bennets receive a post from Mr. Gardiner, stating that the two have been located in London, and that they are to be married. From this update, much relief is to be had, though Mr. Bennet declares that Lydia and her new husband are not welcome in his home, a declaration which is quickly overturned by Mrs. Bennet.

Shortly thereafter, the couple returns, newly married, and as pompous as ever. While there, Lydia is indulged more than ever by her mother, and boasts non-stop about being married. One day, as the sisters are sitting down together, Lydia relays the particulars of her wedding to Elizabeth, when she accidentally tells her that Darcy was at the wedding. "Oh, yes! - he was to come there with Wickham, you know. But gracious me! I quite forgot! I ought not to have said a word about it. I promised them so faithfully! What will Wickham say? It was to be such a secret" (Austen, 2012, p. 
608). Here, Mr. Darcy has committed a positive violation against Elizabeth. She has assumed up until now that all hope is lost, but now knows that it never was (Bonito et. al., 1999). Upon acquiring this knowledge, Elizabeth writes to her aunt Gardiner, and receives confirmation that Darcy, who assumes responsibility for the entire affair, located Lydia and Wickham, forced them to get married, and paid off all of Wickham's debts, with the condition that Mr. Gardiner accept the credit. Receiving this information from her beloved and trusted aunt is the best news in the world for Elizabeth (Bonito et. al., 1999). Shortly after this revelation, Darcy, along with the Bingley's return to Netherfield, and Darcy subsequently confesses to Bingley that he intentionally withheld information from the latter, and that he should never have interfered in his and Jane's relationship. Bingley then returns to Longbourn and, at long last, proposes to Jane. When Elizabeth sees how content her sister is, knowing that this newfound happiness can be credited to Mr. Darcy's willingness to admit his wrongdoing, it is then that her expectations are truly exceeded, all is forgiven, and she proudly accepts the title of Mrs. Darcy.

Pride and Prejudice is as much an "And They All Lived Happily Ever After" story as there ever was. However, Elizabeth Bennet and Mr. Darcy's journey is not an easy one. From the very beginning of their acquaintance Darcy violates Elizabeth's expectations, and in return, Elizabeth creates an alliance with his arch nemesis, Mr. Wickham, falling into the self-deceptive trap, willingly believing Wickham's lies because Darcy has humiliated her pride. In fact, it's only on account of Wickham's selfish carelessness that Elizabeth and Darcy eventually end up together. 
As stated before, self-deception is "an arrogant self-presentation" "whereby we construct an image of ourselves more pleasing to ourselves" (Grenberg, 2015, p. 164). According to Demos, self-deception exists "when a person lies to himself, that is to say, persuades himself to believe what he knows is not so" (Demos, 1960, p. 588). Elizabeth gives into this trap several times throughout the novel, and only changes her mind when she finds that it is impossible not to do so.

Elizabeth Bennet does not despise Mr. Darcy "simply because he is rich" (Waldron, 1999, p. 55). Instead, she has three very good reasons for disliking him, three reasons that are all revealed by violations of her expectations. At their first meeting, he insults her and humiliates her pride. Later on, she is told that he has driven her friend, Mr. Wickham, into poverty. Finally and worst of all, she has reason to believe that he has damaged the relationship between her sister and Mr. Bingley. In spite of her rationale, Elizabeth Bennet "is still prepared to judge people on what she thinks are their merits" (p. 55). Unfortunately, her wounded pride prevents her from seeing what those merits are.

Darcy's initial insult of Elizabeth "is founded on social prejudice" (Litz, 1969, p. 63). He "is mindful of his relationship to society, proud of his place, and aware of the restrictions that inevitably limit the free spirit" (Litz, 1969, p. 65). Elizabeth, who doesn't yet understand his character, takes it more as a personal affront, and develops a prejudice against him, "rooted in pride of her own quick perceptions" (Litz, 1969, p. 63). Contrary to Darcy's worldview, "Elizabeth possesses the illusion of total freedom" (Litz, 1969, p. 65). She pays no mind to societal or traditional authorities, but instead relies on her own judgment, and is "proud of her discernment" (p. 65), 
loathing "all conventions that constrict the individual's freedom" (p. 65). When Elizabeth first meets Darcy, her judgment is based on "superficial facts and behavior, not on a firm understanding of the man" (Teachman, 1997, p. 15). Only observing his "outer pridefulness" (p. 15), Elizabeth has no knowledge of "his upbringing, his family situation, and his past behavior" (p. 15), and although she should not necessarily "excuse his behavior in all circumstances" (p. 15), he is "judged unfairly" (p. 15), when considering how long she holds his first performance against him.

Her unceasing bitterness can be seen a short time later when her sister, Jane, becomes ill after riding on horseback to Netherfield. Elizabeth follows her sister there, in order to care for her, but spends a majority of her time sparring with Darcy. At one point in particular, he says to her, "there is, I believe, in every disposition a tendency to some particular evil—a natural defect, which not even the best education can overcome" (Austen, 2012, p. 110). Elizabeth responds by saying, "and your defect is to hate everybody" (p. 110), to which he replies, "and yours is willfully to misunderstand them" (p. 110). According to EVT, arousal change causes "an alertness or orienting response that diverts attention away from the ostensive purpose of the interaction and focuses it toward the source of the arousal-the initiator of the violation" (Burgoon \& Hale, 1988, p. 62). For Elizabeth, the initial insult that Darcy makes against her is not about the isolated incident, but instead about who he is as a person. If he can so willingly insult her upon their first meeting, then it must be because he is a conceited individual who takes pleasure in looking down on everyone. In spite of her unkind response, rather than end the conversation and walk away, Darcy reciprocates because according to Burgoon, "violations by high reward 
communicators should elicit approach behavior resulting in reciprocity of increased involvement" (Burgoon \& LePoire, 1994, p. 562), and by this time, Darcy is beginning to form a favorable opinion about Elizabeth Bennet, making her a high reward communicator. During a later meeting, Darcy asks her about her taste in books, but she rebuffs him saying, "Books - Oh! No. - I am sure we never read the same, or not with the same feelings" (Austen, 2012, p. 182). In spite of the fact that Darcy is doing nothing more than making polite conversation, Elizabeth still insists on being ill-mannered. The exchange in its entirety is an attempt for Elizabeth to "understand" Darcy's character, but instead illustrates her "unconscious prejudices" (Litz, 1976, p. 70), and confirms that "communicators cling to their prior expectancies even in the face of disconfirming evidence" (Burgoon, 1993, p. 33).

Wickham, aware of Elizabeth's dislike of Darcy, serves to further that selfdeception. He “delights in pulling Mr. Darcy's character to shreds and is happy to feed Elizabeth's curiosity about him; it's a large part of the reason she is, at first, so taken by him. For her, the uniform has little to do with it" (Kelly, 2017, p. 122). He shares with her a story of how he has been wronged, robbed of his vocation, and thrusted into poverty, due to Darcy's pride and conceit, and Elizabeth doubts none of what he says, taking him fully at his word because Wickham's "sufferings" validate her own opinion of Darcy, further feeding into her self-deception. According to Miri, a "habitual liar tends to repeat his own lies to- himself and to others" (Miri, 1974, p. 581), and can occasionally be "taken in by his own lies" (p. 581). Perhaps, Wickham has told his story so much that even he partially believes what he is saying, making him all the more convincing. As for Elizabeth, her belief comes strictly from her need to believe 
him, and not from a place of truth. Her only real claim against Darcy is on behalf of her sister, and even that is partially grounded in self-deception, for she holds the belief that his interference in her sister's relationship with Bingley is done out of cruelty. The truth is that although he has overstepped his boundaries, Darcy is convinced that based on personal observation, Jane may be unworthy of his friend's affections. When accused of dividing them, Darcy responds, "I have no wish of denying that I did everything in my power to separate my friend from your sister, or that I rejoice in my success. Towards him I have been kinder than towards myself" (Austen, 2012, p. 376). After she dismisses him from her presence, Darcy continues the conversation through a letter, in which he explains his reasoning for the interference. Of it he writes, "I could then perceive that his partiality for Miss Bennet was beyond what I had ever witnessed in him. Your sister I also watched. - Her look and manners were open, cheerful and engaging as ever, but without any symptom of peculiar regard" (Austen, 2012, p. 386). Darcy later admits that he had no business interfering with Jane and Bingley, and in that particular situation, the fault is his own. However, by the conclusion of this letter, in which he not only explains his interference, but also reveals Wickham's true character, Elizabeth herself is starting to understand his reasoning and question her own.

According to Burgoon, there are "societal norms for what is typical and appropriate behavior" (Burgoon, 1993, p. 31), which create what Backman refers to as "shared understandings and rules" (Backman, 1985, p. 272). When Darcy violates her expectations by failing to conform to the societal norms of politeness, and effectively breaking these rules, Elizabeth condemns him for something he is not (Manrique, 
2007). It isn't until she reevaluates her own prejudices and short-sightedness, and is faced with a reality that she previously refuses to see, and that reality is that you can't always base your judgments on First Impressions. 


\section{Conclusion}

This thesis has explored the central relationships in Sense and Sensibility and Pride and Prejudice. In analyzing these relationships through the lens of EVT, I looked at each valence within the theory, and examined how violations in expectations can reveal traces of self-deception. An interesting aspect of the two core relationships studied was that each had an outside individual influencing the progression of the relationship. This raised the question as to whether violations of expectations would have been so impactful, had these external influences not been present. For example, if Marianne had never met Colonel Brandon in Sense and Sensibility, would she have continuously longed for Willoughby until she died from a broken heart, or alternatively, if Colonel Brandon were younger and more to Marianne's liking, would she have been able to move on from Willoughby more quickly? And in Pride and Prejudice, if Wickham never joined the regiment and had, therefore, never been present to put ideas into Elizabeth's mind about Darcy, would that have lessened her overall disgust toward him when he proposed? Further, would Elizabeth and Darcy even have ended up together if Wickham wasn't around, or were his violations required in order for that to happen?

When discussing the concept of self-deception, another question arose as to how Marianne's became so dangerous. Could her self-deception be caused by what she believed to be a lousy selection of alternative suitors (Colonel Brandon), fueled strictly by her own self-absorption, or a steady combination of both?

An additional idea that came to mind while doing this study was to explore these novels through the lens of EVT using other characters. In Pride and Prejudice, 
for example, Elizabeth's friend, Charlotte, violates her expectations when she marries the stupidest man in all of Kent. Such a study could be done on any number of Austen's characters, as so many of them repeatedly defy social norms. An alternative to EVT would be to view Austen's novels through the lens of a different theory, altogether. While conducting my initial research for this project, I discovered that the works of Austen were rarely paired with theories of communication, so the options for such explorations are virtually endless.

The goal of this study was to apply EVT to Austen's works in order to offer an alternative perspective on her novels, examine how this unique angle increases the value of her stories, reveal how this theory can uncover self-deception, and illustrate why her work is still significant today. This was accomplished by dissecting the theory, displaying how well Austen's relationships adhere to its contours, and how easily her characters fall into the self-deceptive trap, and therefore, demonstrates that not only does the theory increase the value of the novel, but also how the novel validates the theory, in turn. It also speaks volumes about Austen and her talent for understanding the intricacies of interpersonal relationships, as well as her uncanny insights into human limitation. 


\section{Bibliography}

Adams, T. D. (1982). To know the dancer from the dance: dance as a metaphor of marriage in four novels of Jane Austen. Studies in the Novel, 14(1), 55-65.

Agosta, S., Pezzoli, P., \& Sartori, G. (2013). How to Detect Deception in Everyday Life and the Reasons Underlying It. Applied Cognitive Psychology, 27, 256-262.

ApRoberts, R. (1975). Sense and Sensibility, or Growing Up Dichotomous. Nineteenth-Century Fiction, 30(3), 351-365.

Ashfaq, S. (2014). Self-deception vs. Self-realization. Dialogue (Pakistan), 9(1).

Austen, J. (1813). The Annotated Pride and Prejudice. 2nd ed. (2012) Ed. J.M.

Shapard. Anchor.

Austen, J. (1811). The Annotated Sense and Sensibility. (2011) Ed. J.M. Shapard. Anchor.

Backman, C. W. (1985). Identity, Self-Presentation, and the Resolution of Moral Dilemmas: Towards Social Psychological Theory of Moral Behavior. Ed. B.R. Schlenker. The Self and Social Life, 261-289, New York: McGraw Hill.

Barry, B., \& Crant, J. (2000). Dyadic Communication Relationships in Organizations: An Attribution/Expectancy Approach. Organization Science, 11(6), 648-664.

Bartholow, B., Fabiani, M., Gratton, G., \& Bettencourt, B. (2001). A Psychophysiological Examination of Cognitive Processing of and Affective Responses to Social Expectancy Violations. Psychological Science, 12(3), 197 204. 
Beattie, M. (1992). Codependent No More. (2nd Ed.). Hazelden.

Bernstein, A. J. (2001). Emotional Vampires: Dealing with People Who Drain You Dry. MJF Books.

Bonito, J. A., Burgoon, J. K., \& Bengtsson, B. (1999). The Role of Expectations in Human-Computer Interaction. In Proceedings of the International ACM SIGGROUP Conference on Supporting Group Work, 229-238.

Bonus, J. A., Matthews, N. L., \& Wulf, T. (2019). The Impact of Moral Expectancy Violations on Audiences' Parasocial Relationships with Movie Heroes and Villains. Communication Research, 1-23.

Brower, R. A. (1951). Light and Bright and Sparkling: Irony and Fiction in Pride and Prejudice. Jane Austen: A Collection of Critical Essays. Ed. Ian Watt. 1963, 6275. Prentice-Hall Inc.

Bryant, E. (2008). Real Lies, White Lies and Gray Lies: Towards a Typology of Deception. Kaleidoscope, 7, 23-48.

Burgoon, J. K. (2015). Expectancy Violations Theory. The International Encyclopedia of Interpersonal Communication, 1-9.

Burgoon, J. K. (1995). Cross-cultural and intercultural applications of expectancy violations theory. Ed. R. Wiseman. Intercultural communication theory, 194-215.

Burgoon, J. K. (1993). Interpersonal expectations, expectancy violations, and emotional communication. Journal of Language and Social Psychology, 12(1-2), $30-48$. 
Burgoon, J. K., \& Hale, J. L. (1988). Nonverbal expectancy violations: Model elaboration and application to immediacy behaviors. Communications Monographs, 55, 58-79.

Burgoon, J. K., Kelley, D. L., Newton, D. A., \& Keeley-Dyerson, M. P. (1989). The Nature of Arousal and Nonverbal Indices. 217-255.

Burgoon, J. K., \& Le Poire, B. A. (1994). Two contrasting explanations of involvement violations: Expectancy violations theory versus discrepancy arousal theory. Human Communication Research, 20(4), 560-591.

Chandler, A. (1975). “A Pair of Fine Eyes”: Jane Austen's Treatment of Sex. Jane Austen. Ed. Harold Bloom. 1986, 27-42. Chelsea House Publishers

Davidson, J. (2017). Reading Jane Austen. Cambridge University Press.

Demos, R. (1960). Lying to Oneself. The Journal of Philosophy, 588-595.

Duckworth, A. M. (1971). The Improvement of the Estate: A Study of Jane Austen's Novels. The Johns Hopkins Press. Baltimore \& London.

Elsbree, L. (1960). Jane Austen and the Dance of Fidelity and Complaisance. Nineteenth-Century Fiction, 113-136. University of California Press.

Garis, R. (1968). Learning experience and change. Critical Essays on Jane Austen. Ed. BC Southam. 60-82. London: Routledge \& Kegan Paul.

Garrod, H.W. (1928). Jane Austen: A Depreciation. Ed. W. Heath. Discussions of Jane Austen. 1961, p. 39. Boston: D.C. Heath and Company. 
Gigliotti, R. (1987). Are They Getting What They Expect? Teaching Sociology, 15(4), 365-375.

Gigliotti, R. (1987). Expectations, Observations, and Violations: Comparing Their Effects on Course Ratings. Research in Higher Education, 26(4), 401-415.

Gillie, C. (1985). A Preface to Jane Austen: Revised Edition. Longman Group Ltd.

Goodheart, E. (2008). Emma: Jane Austen's Errant Heroine. The Sewanee Review, 2008, 589-604. The Johns Hopkins University Press

Gottman, J., \& Gottman, J. S. (2016). The Man's Guide to Women.

Grenberg, J. M. (2015). Self-deception and self-knowledge: Jane Austen’s Emma as an Example of Kant's Notion of Self-Deception. Con-Textos Kantianos. International Journal of Philosophy, 1(2), 162-176.

Griffin, E. (2011). A First Look at Communication Theory.

Halperin, J. (1984). The Life of Jane Austen. The John Hopkins University Press.

Hamlyn, D. W. (1985). Self-Deception. Journal of Medical Ethics, 210-211. BMJ

Hart, F. R. (1975). The Spaces of Privacy: Jane Austen. Nineteenth Century Fiction, 305-334.

Hawkridge, A. (2000). Jane and her Gentlemen: Jane Austen and the Men in her Life and Novels. Peter Owen Limited. 
Helm, W. H. (1909). Jane Austen and Her Country House Comedy. Eveleigh Nash.

Hinnant, C. H. (2006). Jane Austen's "Wild Imagination": Romance and the Courtship Plot in the Six Canonical Novels. Narrative, 294-310. Ohio State University Press.

Janata, P., \& Petsche, H. (1993). Spectral Analysis of the EEG as a Tool for Evaluating Expectancy Violations of Musical Contexts. Music Perception: An Interdisciplinary Journal, 10(3), 281-304.

Johnston, C. D., Lavine, H., \& Woodson, B. (2015). Emotion and political judgment: Expectancy violation and affective intelligence. Political Research Quarterly, 68(3), 474-492.

Jones, E., \& Jones, C. (2012). Feeling better or doing better? On the functions of inconsistency reduction (and other matters). Psychological Inquiry, 23(4), 350353.

Juhasz, S. (1987). Bonnets and Balls: Reading Jane Austen's Letters. The Centennial Review, 84-104.

Kaufmann, D. (1992). Law and Propriety, Sense and Sensibility: Austen on the Cusp of Modernity. 385-408. ELH.

Kauvar, E. (1970). Jane Austen and the Female Quixote. Studies in the Novel, British Neo-Classical Novel, 211-221. The Johns Hopkins University Press

Kaye-Smith, S., \& Stern, G. B. (1949). More about Jane Austen. Harper. 
Kaye-Smith, S., \& Stern, G. B. (1944). Speaking of Jane Austen. Harper.

Kelly, H. (2017). Jane Austen, the Secret Radical. Alfred A. Knopf.

Lauber, J. (1993). Jane Austen. Twayne Publishers.

Lescinski, J. (1986). Heroines under Fire: Rebels in Austen and James. CEA Critic: An Official Journal of the College English Association, 60-69.

Lin-Hi, N., Hörisch, J., \& Blumberg, I. (2015). Does CSR Matter for Nonprofit Organizations? Testing the Link Between CSR Performance and Trustworthiness in the Nonprofit Versus For-Profit Domain. Voluntas: International Journal of Voluntary and Nonprofit Organizations, 26(5), 1944-1974.

Litz, A. W. (1976). 'A Development of Self': Character and Personality in Jane Austen's Fiction. Ed. Juliet McMaster. Jane Austen's Achievement. Bicentennial Conference Papers, 1976, 64-78. The Macmillan Press Ltd.

Litz, A. W. (1965). Into the Nineteenth Century: Pride and Prejudice. Ed. E Rubinstein. Twentieth century interpretations of Pride and prejudice: a collection of critical essays, 1969, 59-69. Prentice-Hall.

Manrique, F. M. (2007). Attributions of Self-Deception. Teorema, 26(3), 131-143.

Margulis, E. (2005). A Model of Melodic Expectation. Music Perception: An Interdisciplinary Journal, 22(4), 663-714.

Maslow, A. H. (1965). Self-actualization and beyond. New England Board of Higher Education. Winchester, MA. Report resume. In Proceedings of the Conference on the Training of Counselors of Adults, Chatham, MA, 107-131. 
Metts, S., \& Grohskopf, E. (2003). Impression Management: Goals, Strategies and Skills. Eds. J. O. Green, \& B. R. Burleson. Handbook of Communication and Social Interaction Skills, 357-399. Routledge.

Miller, C. R. (2005). Jane Austen's Aesthetics and Ethics of Surprise. Narrative, 238260. Ohio State University Press.

Minma, S. (2001). Self-Deception and Superiority Complex: Derangement of Hierarchy in Jane Austen's Emma. Eighteenth-Century Fiction, 14(1), 49-65.

Miri, M. (1974). Self-deception. Philosophy and Phenomenological Research, 34(4), 576-585.

Moler, K. (1968). Jane Austen's Art of Illusion. University of Nebraska Press.

Monaghan, D. (1975). The Decline of the Gentry: A Study of Jane Austen's Attitude to Formality in "Persuasion". Studies in the Novel, 73-87. The Johns Hopkins University Press

Morgan, S. (1980). In the Meantime: Character Perception in Jane Austen's Fiction. University of Chicago Press.

Morini, M. (2007). Who Evaluates Whom and What in Jane Austen's Novels? Style, 409-432. Penn State University Press

Niehuis, S., Reifman, A., Weiser, D. A., Punyanunt-Carter, N. M., Flora, J., Arias, V. S., \& Oldham, C. R. (2019). Guilty Pleasure? Communicating Sexually Explicit 
Content on Dating Apps and Disillusionment with App Usage. Human Communication Research, 55-85.

Nixon, C. L. (1998). Balancing the Courtship Hero: Masculine Emotional Display in Film Adaptations of Austen's Novels. Ed. L. Troost and S. Greenfield. Jane Austen in Hollywood. 22-43. The University Press of Kentucky.

Palmer, S. B. (2016). "Self-Deceived, I Did Deceive You": Confabulation in Emma. CEA Critic, 78(3), 356-362.

Palmer, A. (1979). Characterising Self-deception. Mind, 88(349), 45-58.

Paris, B. J. (1978). Character and Conflict in Jane Austen's Novels: A Psychological Approach. Waynes State University Press.

Pinion, F. B. (1973). A Jane Austen companion: a critical survey and reference book. Springer.

Poovey, M. (1984). Ideological Contradictions and the Consolations of Form: The Case of Jane Austen. Ed. L Mooneyham White. Critical Essays on Jane Austen. 67-102. G. K. Hall \& Company.

Posusta, R. (2014). Architecture of the Mind and Place in Jane Austen's "Persuasion". Critical Survey, 76-91. Berghahn Books.

Prioleau, B., \& Prioleau, E. S. (2013). Swoon: Great Seducers and Why Women Love Them. WW Norton \& Company. 
Proulx, T., \& Inzlicht, M. (2012). The Five "A"s of Meaning Maintenance: Finding Meaning in the Theories of Sense-Making. Psychological Inquiry, 23(4), 317335.

Randles, D., Heine, S., \& Santos, N. (2013). The Common Pain of Surrealism and Death: Acetaminophen Reduces Compensatory Affirmation Following Meaning Threats. Psychological Science, 24(6), 966-973.

Roberts, J. A., \& David, M. E. (2019). Boss phubbing, trust, job satisfaction and employee performance. Personality and Individual Differences, 155.

Ryle, G. (1968). Jane Austen and the Moralists. Ed. BC Southam. Critical Essays on Jane Austen. 1966, 106-122. London: Routledge \& Kegan Paul.

Scott, G. G. (2016). Lies and Liars: How and Why Sociopaths Lie and How You Can Detect and Deal with Them. Skyhorse Publishing.

Segal, D. A., \& Handler, R. (1989). Serious Play: Creative Dance and Dramatic Sensibility in Jane Austen, Ethnographer. Man, 322-339. Royal Anthropological Institute of Great Britain and Ireland.

Shoben, E. J. Jr. (1982). Impulse and Virtue in Jane Austen: Sense and Sensibility in Two Centuries. The Hudson Review, 521-539.

Smith, G. (1972). Life of Jane Austen. (2nd Ed.). Kennikat Press.

Stovel, B. (1989). Secrets, Silence, and Surprise in Pride and Prejudice. Persuasions: Journal of the Jane Austen Society of North America, 85-91. 
Szabados, B. (1974). Self-Deception. Canadian Journal of Philosophy, 51-68.

University Press

Tanner, T. (1986). Jane Austen. Harvard University Press.

Taschereau, C. E. (1977). The development of individuality in the male characters in Jane Austen's novels (Doctoral dissertation, University of Rhode Island).

Tave, S. M. (1973). Some Words of Jane Austen. The University of Chicago Press and London.

Teachman, D. (2017). Understanding Pride and Prejudice: A Student Casebook to Issues, Sources, and Historical Documents. Greenwood Press.

Thomason, L. (2015). The Dilemma of Friendship in Austen's "Emma". The Eighteenth Century, Jane Austen and Her Contemporaries, 227-241. University of Pennsylvania Press.

Valihora, K. (2010). Austen's Oughts: Judgment after Locke and Shaftesbury. University of Delaware Press.

Waldron, M. (1999). Jane Austen and the Fiction of Her Time. Cambridge University Press.

White, C. H. (2008). Expectancy violations theory and interaction adaptation theory. Ed. Baxter \& Braithwaite. Engaging theories in interpersonal communication, 189-202. 
Wilson, S. R., \& Sabee, C. M. (2003). Explicating communicative competence as a theoretical term. Eds. J. O. Greene \& B. R. Burleson. Handbook of communication and social interaction skills, 3-50. Lawrence Erlbaum Associates Publishers.

Zunshine, L. (2007). Why Jane Austen was different, and why we may need cognitive science to see it. Style, 41(3), 275-298. 